\title{
Sedimentary sequences in the Gulf of Lion: A record of 100,000 years climatic cycles
}

\author{
Marina Rabineau ${ }^{\mathrm{a}, \mathrm{b}, \star}$, Serge Berné ${ }^{\mathrm{b}}$, Daniel Aslanian ${ }^{\mathrm{b}}$, Jean-Louis Olivet ${ }^{\mathrm{b}}$, Philippe Joseph $^{\mathrm{c}}$, François \\ Guillocheau $^{d}$, Jean-François Bourillet ${ }^{b}$, Eliane Ledrezen ${ }^{b}$ and Didier Granjeon ${ }^{c}$
}

\author{
aUMR6538 Domaines Océaniques, 1 Place Nicolas Copernic, 29280 Plouzané, France \\ bIFREMER (Institut Français de Recherches pour l'Exploitation de la Mer), DRO/GM, Laboratoire \\ Environnements Sédimentaires, BP 70, 29280 Plouzané, France \\ clFP (Institut Français du Pétrole) Division Géologie-Géochimie, BP311, 92506 Rueil Malmaison, France \\ dGéosciences Rennes, Université de Rennes 1, 35042 Rennes, France
}

*: Corresponding author : m r a b in e a @ u n i v - b r e s t . f r ; F ax : 33-(0)298-49-87-60

\begin{abstract}
:
The wide continental shelf of the Gulf of Lion (up to $70 \mathrm{~km}$ ) has been the object of numerous investigations since the early days of oceanography. Yet, the question of sequences duration, the mechanisms of deposition and factors implied remained unanswered. A study of a very dense grid of Very High Resolution (VHR) seismic reflection (Sparker) data associated with surficial cores both, collected by IFREMER between 1992 and 2001 on the outer shelf and upper slope offshore of Sète in the Languedoc region gives a new insight into these issues. Analysis of the 3D geometry of the sedimentary record reveals a basic depositional pattern consisting of a pair of horizontally juxtaposed and downlapping prisms. Prism PI with low angle clinoforms $\left(<1^{\circ}\right)$ lies on the upper part of the shelf and is interpreted to be prodeltaic-offshore deposits. Prism PII with steeply dipping clinoforms $\left(4^{\circ}\right)$ lies on the outer shelf between 40 and $70 \mathrm{~km}$ from the present day coastline and is interpreted to be littoral deposits.
\end{abstract}

Results obtained from integrating lithology, palynology, micropaleontology, seismic stratigraphy, stratigraphic simulation, support the hypothesis that the basic depositional pattern records a 100000 years glacioeustatic (interglacial/glacial) cycle. As previously suggested by Aloïsi [Aloïsi, J.C., 1986. Sur un modèle de sédimentation deltaïque: contribution à la connaissance des marges passive, Thèse de Doctorat d'Etat. Université de Perpignan, 162 pp], prisms PI corresponds to deposition at high sea level and prisms PII to deposition during low sea level at glacial maxima. Five sequences of paired prisms capped by five major erosion surfaces have been identified and modelled showing that the corresponding glacioeustatic cycles (the last five cycles at least) are recorded on the shelf of the western part of the Gulf of Lion.

Keywords: Western Mediterranean; Gulf of Lion; Sequences; Climatic cycles; Glacioeustatism; Highresolution seismic data; Cores; Stratigraphic modelling 


\section{Keywords: Western Mediterranean, Gulf of Lion, Sequences, Climatic cycles, Glacioeustatism, High-resolution seismic data, Cores, Stratigraphic modelling.}

\section{Introduction}

Ocean sediments are important archives of Earth's history and record of climatic, environmental, hydrodynamic and geodynamic changes. Continental margins, in particular, favour long-term and continuous accumulation of sedimentary strata and provide opportunities to study the impact and the interplay of changes on the sedimentary system. The vertical stacking of sedimentary facies and surfaces allows deduction of lateral evolution of environments through time (Walther Law, 1894 in (Lombard, 1956)). Time is registered either within a sedimentary body or by a discontinuity surface. Observation and analysis of sedimentary strata, identification of sequences within the series enables the reconstruction of paleoenvironments and paleogeographies that describe the spatio-temporal evolution of sediment deposition: what kind of sediments are deposited and preserved, and how, when, with what geometry? What are the relationships between sedimentary sequences, Quaternary glacioeustatic cycles and tectonics?

Many factors of global, regional or local scale have long been recognised to control the overall geometry and deposition of sediments. Seismic stratigraphy was developped at the end of the 70's, to address part of those questions that were critical for petroleum exploration (Payton, 1977). At the end of the 80's Sequence Stratigraphy developed with a conceptual model that links the formation of sequences and their resulting geometries to a cycle of variation of relative sea-level (or accommodation). Most authors working on sequence stratigraphy recognised that eustasy, tectonic and sediment flux are the three main factors that control variations in accommodation and therefore geometries of sequences (Guillocheau, 1990; Homewood, Guillocheau, Eschard \& Cross, 1992; Jervey, 1988; Posamentier, Jervey \& Vail, 1988a) for instance. Three main systems tracts: the Highstand System Tract (HST), the Lowstand System Tract (LST), the Transgressive System Tract (TST) are defined according to their position on the relative sea level curve (Posamentier \& Vail, 1988b; Vail, Colin, Du Chene, Kuchly, Mediavilla \& Trifilieff, 1987). They are limited by three types of surfaces (the Sequence Boundary: the unconformity related to the inflexion point of lowering sea level; the Transgressive Surface: when relative sea level starts to increase again; the Maximum Flooding Surface: when the 
relative sea level is at its highest level) (Posamentier, Jervey \& Vail, 1988a; Posamentier \& Vail, 1988b; Vail, et al., 1987). In parallel, the model of Genetic Sequence was developed with a different approach based on the recognition of the smallest individual units and their vertical stacking pattern (mainly on outcrops and cores interpretation) (Cross, 1988; Cross, Baker, Chapin, Clark, Gardner, Hanson, et al., 1993; Galloway, 1989; Guillocheau, 1991; Homewood, Guillocheau, Eschard \& Cross, 1992).

In the 1990's distinct sedimentary bodies on the shelf called: "sharp based shoreface sandstone encased in shales" are described and interpreted as deposited during relative sea-level fall. This model of deposition corresponds to the concept of forced regression and Falling Stage Systems Tract (FSST) (Hunt \& Tucker, 1992; Plint, 1988; Plint \& Nummendal, 2000; Posamentier, Allen, James \& Tesson, 1992) that were not described in the initial Exxon Seismic Stratigraphy model. During the Pleistocene, highstand conditions with a warm climate comparable to present day conditions represent less than $10 \%$ of the last $800 \mathrm{ka}$. Sea level variations are intense and dominated by the falling part of the glacioeustatic cycles. Therefore the model of FSST is widely recognised for Pleistocene sedimentation on continental margins and especially in the Mediterranean Sea. (Berné, Lericolais, Marsset, Bourillet \& de Batist, 1998a; Hernandez-Molina, Somoza \& Lobo, 2000; Rabineau, Berné, Ledrezen, Lericolais, Marsset \& Rotunno, 1998; Tesson, Allen \& Ravenne, 1993; Tesson, Gensous, Allen \& Ravenne, 1990b; Tesson, Posamentier \& Gensous, 2000; Tesson, Ravenne \& Allen, 1990a; Torres, Savoye \& Cochonat, 1995b) in the Gulf of Lion; (Hernandez-Molina, Somoza \& Lobo, 2000; Somoza, HernandezMolina, De Andres \& Rey, 1997) in the Gulf of Cadiz, (Trincardi \& Correggiari, 2000) in the Adriatic, (Piper \& Aksu, 1992) in Western Turkey; (Chiocci, Ercilla \& Torres, 1997) in different parts of the western Mediterranean.

However, the time span for the deposition of the strata has been a matter of debates in the last 30 years ( $20 \mathrm{ka}$ vs $100 \mathrm{ka}$ ) and the controversy was still unresolved in 2000. We review and summarize the differrent and successive interpretations in this paper.

Quantitative numerical models are developed in Earth Sciences to try to reproduce natural phenomena. They are generally based on a fundamental equation (theoretical or semi-empirical), boundary conditions, simplifications and equations resolution. The aim of stratigraphic simulation is to reproduce numerically the observed geometries in a sedimentary basin and to test and quantify, the different parameters involved (eustatism, tectonism, sediment 
input). The underlying principle is to create a given amount of accommodation (i.e. space available for sedimentation), to introduce a volume of sediments and to distribute these sediments into space. Of course, models are efficiently applied only when the geological context and the resulting geometries observed are known in details. It enables to test different hypothesis on sequence timing and duration for example.

In this paper, we therefore used seismic stratigraphic interpretations, information from cores (sampling the uppermost sequence) and numerical stratigraphic simulation, to resolve the long term controversy on sequence duration and show that at least five sequences of 100,000 years are recorded on the outer shelf of the Gulf of Lions with a distinct "motif". Deposits of lowering and lowsatnd se level are capped by discontinuities related to the glacial maxima, i.e. the lowest stand of sea level, of each cycle. This exceptional preservation is due to a high subsidence rate, and an equilibrium between controlling factors. This analysis of sediments deposition in the Gulf of Lion, in turn, validates the concept of FRSST.

\section{General Setting and background}

\section{1-Fluvial Input}

The Mediterranean Sea is a land-locked basin linked to the global oceanic system through the Gibraltar Strait; it is surrounded by continents with variable altitudes (many above $500 \mathrm{~m}$ ) and with the presence of high mountains less than $40-80 \mathrm{~km}$ away from the coast. This small ocean is particularly sensitive to climatic variations. In the Western Mediterranean Sea, the main drainage basin (with a total area around $100000 \mathrm{~km}^{2}$ ) is the Rhodanian basin with its major river, the Rhone, which transports sediments eroded mainly from the Alps. Much smaller drainage basins and rivers come from the Pyrénées (Aude, Agly, Têt and Tech rivers) and from the Massif Central in the Languedocian region (Hérault). These drainage basins are each less than $5000 \mathrm{~km}^{2}$, the biggest is the Aude's $\left(4800 \mathrm{~km}^{2}\right)$, the smallest the Tech $(470$ $\mathrm{km}^{2}$ ).

The present climate in the Gulf of Lion is characterised by frequent and violent winds, a mean moderate precipitation but concentrated in a few days. Violent floods and downpours, enhanced by sparse vegetation and a steep longitudinal profile (slopes reach 0,35-0,85 \%o for the Rhône (Arnaud-Fassetta, Bruzzi, 
L'Homer, Provansal, Sabatier, Suanez, et al., 1999)), transport a high quantity of materials eroded from the mountains. The nature of sediment eroded is very variable but rich in sands and allows contrasted materials to be deposited.

Present day sediment load of the Rhône is 2 to $810^{6} \mathrm{t} \mathrm{yr}^{-1}$ (Arnaud-Fassetta, et al., 1999), however those values decreased substantially since the construction of dams on the Rhône. At the beginning of the twentieth century (prior to dam construction), solid flows (suspended load) are estimated to be between 30 and $6010^{6} \mathrm{t} \mathrm{yr}^{-1}$ for the Rhône (CSCF, 1984; Pauc, 1970). Solid flows (suspended load) from the Pyrenean and Languedocian rivers is much smaller with a maximum of 1.8 to $410^{6} \mathrm{t} \mathrm{yr}^{-1}$ for the Aude, $0.610^{6} \mathrm{t} \mathrm{yr}^{-1}$ for the Têt (CSCF, 1984). The hydrological regime of those smaller rivers is torrential with very variable sediment discharge. Their flow can vary considerably from 5 to 3000 $\mathrm{m}^{3} \mathrm{~s}^{-1}$ in 24 hours during floods (for the Aude for instance), especially in automn, winter and sping (Fig. 1).

\section{2- Oceanographic regime}

The shelf of the Gulf of Lion is characterised by a moderate wave-energy regime dominated by swells (Millot, 1990). Sediment is transported in the Gulf by the General current, currents induced by winds, currents due to swells, and currents due to internal waves. Close to the shoreline, longshore currents due to breaking waves transport sediment. The general current (geostrophic current also called the Northern Current) in the Gulf of Lion corresponds to a flow of 1$210^{6} \mathrm{~m}^{3} \mathrm{~s}^{-1}$ that follows the continental slope to the west and south-west at Cap Creus (Millot, 1990) (Fig. 2). This current is $30-50 \mathrm{~km}$ wide with surface velocities of $50 \mathrm{~cm} \mathrm{~s}^{-1}$ and a few $\mathrm{cm} \mathrm{s}^{-1}$ at several hundred meters of water depth (Millot, 1990). Currents due to waves reach $1 \mathrm{~m} \mathrm{~s}^{-1}$ and affect both the coastal zone and the shelf (Fig. 2). Fortynine percent of the time waves are less than 1 $\mathrm{m}$ high with a wavelength of $4 \mathrm{~s}$ and a maximum wave action of $12 \mathrm{~m}$ (Bruzzi, 1998). During extreme weather (occurring about $0,1 \%$ of the time) waves (often coming from the SW) can reach $5 \mathrm{~m}$ with wave period of $8 \mathrm{~s}$. These induce a velocity that can reach $20 \mathrm{~cm} \mathrm{~s}^{-1}$ at about $50 \mathrm{~m}$ depth (Millot, 1990).

\section{3- Earlier work in the Gulf of Lion}

The continental shelf of the Gulf of Lion has been the object of numerous investigations since the early days of oceanography. Marsili and Donatti sampled the first drag of bottom sediments in 1780; one century later Delesse proposed bathymetric maps based on measures with a plumb line. He also 
described the distribution of sediments in the Gulf with coastal muddy deposits down to $40 \mathrm{~m}$ water depth, then a belt of sandy deposits called « les sables du large » or "sables roux » on the outer shelf, and finally on the slope, muddy sediments again (Delesse, 1871). The very first submarine photograph was also taken in the Gulf of Lion by (Boutan, 1893). The Lacaze-Duthiers and Cap Creus canyons (called Rech in Catalan) were discovered in 1894 by Pruvôt (Pruvôt, 1894 in (Bourcart, 1948)). Bourcart also spent many years studying the canyons and trying to understand their origin (Bourcart, 1947; Bourcart, 1948; Bourcart, $1956 \mathrm{~b}$ for example). The Rhodanian deltaic complex was first studied in its subaerial part in the 1950's (Van Andel, 1950; Kruit, 1955; DuboulRazavet, 1956; Van Straaten, 1957; Lagaaij \& Kopstein, 1964 ... as quoted and referenced in Aloïsi, 1986). Soon its submarine part was also studied with cores and dredges. Many detailed analysis (e.g. mineralogy, granulometry, radioactivity, faunal and microfaunal assemblage) were conducted (Duplaix et Lalou, 1949; 1951; Vatan, 1949; Duboul-Razavet, 1954; Blanc, J.J., 1959; BlancVernet, 1969; Chamley, 1971... for full synthesis and references see in Aloïsi, 1986). In the 1960's Shell's group collected cores as long as $70 \mathrm{~m}$ from the delta. Their precursor work, including the description of facies, sedimentary environments and sequences is still a reference for deltaic facies models (Lagaaij \& Kopstein, 1964; Oomkens, 1967; Oomkens, 1970).

Stratigraphy of the Gulf of Lion shelf has been interpreted differently by previous investigators. In this part we present a synthesis of previously published data (Fig. 3), with a correlation of nomenclatures and interpretations (Table 1).

\subsubsection{Group 1: Monaco, Got, Aloïsi et al (1970-1980's)}

The first view of strata in marine environments is progressively built in the seventies and eighties (Alinat, Hinz \& Leenhardt, 1970; Got, Monaco \& Reyss, 1969; Monaco, 1971; Reyss, 1969)...) especially because of major technical advances in acoustic bathymetry and ultra high resolution to high resolution seismic data acquisition. The first comprehensive view of the Gulf of Lion is progressively built with an impressive work of cartography. Morphosedimentary maps showing the distribution and nature of sediments on the entire shelf and upper slope and isopach maps of the Holocene are published (Aloïsi, Got, Monaco \& Duboul-Razavet, 1973; Aloïsi, Got, Monaco \& Duboul-Razavet, 1973; Got, 1973; Monaco, 1971). Fig. 2 presents a simplified compilation of those results. The first stratigraphic models of Quaternary sedimentation were also proposed (Aloïsi, Monaco, Thommeret \& Thommeret, 
1975c; Got, 1973; Monaco, 1971). Six units labelled a1 to a6 are interpreted as related to glacioeustatic changes of sea level with alternating phases of erosion and sedimentation correlated to major phases of glaciation known in the Alps (Würm, Riss, Mindel) separated by phases of interglacials (Table 1).

In 1986, Aloïsi presented a coherent model for the deltaic sedimentation on the shelf. He based his interpretation on a combined analysis (using cores and seismic profiles) of recent shelf sedimentary bodies and a longer time-scale seismic stratigraphic analysis.

Late Holocene deposits (High Stand Deposits) form a prism (called Epicontinental Sedimentary Prism: ESP) that results from the interaction or fluvial and marine processes (Fig. 3). Upper Pleistocene deposits are made up of, at least, 3 major depositional sequences (SqI, SqII, SqIII), developped on the outer shelf and pinching out landward around $60-80 \mathrm{~m}$ water depth, separated by 4 major erosion surfaces (SI, SII, SIII, SIV) (Fig. 3, Table 1).

It is inferred that a sedimentary wedge equivalent to the Holocene ESP also formed during previous Quaternary sea-level fluctuations but is differentially preserved because of erosion.

-During falling sea level, the ESP progrades, and the shallow part of the deposit is progressively eroded, allowing the preservation of the prodeltaic silty deposits only (SqI, SqII, SqIII) sometimes capped by alluvial terraces.

-During the lowest sea level (relative sea level lowstand) more than $50 \%$ of the shelf underwent subaerial erosion. On the outer shelf in the western part of the Gulf of Lion, sandy prograding units interpreted as littoral sands are deposited over more than $30 \mathrm{~km}$ across the shelf (Fig. 2).

-During rising and high sea level, transgressive and high stand sediments are deposited on the inner shelf.

The erosion surfaces were correlated by Aloïsi (1986) to major phases of glaciation recognised on land and called, in the Alps, Würm IV, Würm III, Riss, Mindel (Table 1). Sequences are therefore interpreted as deposited during major glacial/interglacial cycles (of the order of 100,000 years, except for the last 2 surfaces that were part of one single glacial/interglacial cycle). The successive sand bodies were interpreted as being deposited during the lowest sea level and represented the glacial maximum shoreline.

\subsubsection{Group 2: Tesson, Gensous et al., 1990's}

Tesson and Gensous studied the Eastern part of the Gulf of Lions and applied the newly developed sequence stratigraphic concepts (Tesson, Allen \& Ravenne, 1993; Tesson, Gensous, Allen \& Ravenne, 1990b; Tesson, Ravenne \& 
Allen, 1989). They described 6 superimposed prograding wedges named a to $f$ that form a complex (Fig. 3 and Table 1). Each wedge was interpreted as a shelf perched lowstand wedge in the sense of Posamentier, 1988b \#1363 interpreted to be deposited during phases of lowering of relative sea level. Tesson et al. (1993) correlated those wedges to glacioeustatic sea level variations: individual wedges are associated to circa 20 ka cycles (5th order of variations in the sense of Mitchum and Van Wagoner (Mitchum \& Van Wagoner, 1991). For Tesson and Gensous, the complex of 6 sequences are all included in the Würm, i.e. in the last 100,000 year cycle (4th order).

After 1995, the study of Languedocian and Roussillon areas led Tesson and Gensous to recognise a more complicated organisation with Regional Prograding Units (RPU) and proximal Intercalated Units (pIU) and distal Intercalated Units (dIU) (Tesson \& Allen, 1995; Tesson, Posamentier \& Gensous, 2000). Six distal IU are therefore added (on the outer shelf) to the simple succession of 6 RPU previously described (Fig. 3). Tesson, Posamentier and Gensous concluded that « these deposits (IUd) constitute deposition of a shortlived stillstand deposit during an overall transgression ». As to the units duration, they proposed that individual RPU were associated « either to 5th order cycles $(20 \mathrm{ka})$ or 4 th order cycles $(100 \mathrm{ka}) »$.

\subsubsection{Group 3: Torres et al., 1995}

In 1995, Torres et al worked on the slope of the Gulf of Lion and described the succession of six major seismic units (A to F); each composed of two sub-units: a transparent subunit and a layered subunit. He correlated A-F units to the work of Tesson and Gensous on the shelf (see previous part). However, Torres et al concluded that the units could not be related to $20 \mathrm{ka}$ cycles and proposed a longer duration for sequences (Table 1)(Chiocci, Ercilla \& Torres, 1997; Torres, 1995; Torres, Savoye \& Cochonat, 1995b).

\section{So, the controversy was still unresolved in 2000.}

\section{Data set and methods}

\subsection{Data set :}

The study area is located around the Aude-Hérault Canyons on the outer shelf between the $90 \mathrm{~m}$ isobath and the shelf break. It was explored with a dense grid of geophysical data and cores (Figs. 1 and 4). 
The geophysical data were acquired during eight cruises from 1994 to 2000 with the research vessels "L'Europe", "Le Suroit" and "L'Atalante". A differential GPS system was employed for accurate (about $5 \mathrm{~m}$ ) positioning. Some data come from previous (1991 and 1992) surveys with the research vessel "Georges Petit", using a Syledis radio-electric positioning system. The main seismic source was a 1500 Joules SIG sparker with a frequency varying between 500 and $2000 \mathrm{~Hz}$. The shooting interval was 1 to $1.5 \mathrm{~s}$. A total of more than $2000 \mathrm{~km}$ of very high resolution and high quality profiles were recorded, both in analogue and digital modes. Their vertical resolution is about $1 \mathrm{~m}$ with a penetration around $500 \mathrm{~ms}$, but the presence of the sub-bottom multiple decreases the amount of usable data. The dense pseudo-3D seismic grid acquired covers a total area of 25 by $28 \mathrm{~km}$, or $700 \mathrm{~km}^{2}$, with a spacing between track lines ranging from 400 to $1500 \mathrm{~m}$. The data were post-processed with a software dedicated to the processing of Very high resolution seismic: SITHERE (Lericolais, Girault, Tofani \& Olagnon, 1991; Lericolais, Olagnon \& Berné, 1994a; Lericolais, Olagnon, Krone \& Nouzé, 1994b; Nouzé, 1993). Processing includes normalisation, band-pass filter, multiple attenuation, time variable gain and spatial coherence.

\subsection{Seismic stratigraphy}

Seismic interpretation has been performed using the principles of seismic stratigraphy, i.e. we identified seismic units according to the reflection configurations, seismic facies identification and associations, geometries analysis. In a first step, we decided to interpret the smallest scale units seen on the profiles. Note that we use here the term unit as a purely descriptive term (and not the term sequence) those small-scale seismic units can be disconnected in space (because of erosion for example) but they can be in fact synchroneous. Reflector depths were checked at all tie-points and digitised interactively on numerical profiles with Sithere with an error lower than $2 \mathrm{~ms}$. A geostatistical analysis and interpolation of data has been performed using Isatis software (developed by Geovariance) in order to obtain isobath and isopach maps of all the units (in ms Twtt) (Fig. 7). We will use the term Sequence as in Sequence Stratigraphy, as an interpretative term, i.e. the resulting geometry of a cycle of variation of relative sea-level (Posamentier, Jervey \& Vail, 1988a) as presented in introduction.

\subsection{Stratigraphic data}

Twenty one shallow cores collected between 1992 and 1997 were also used in this study (Table 2). Piston cores reached a maximum length of 7 meters for 
core 97CLKS11; whereas vibrocores reached a maximum length of 2,35 m. See Table 2 for a summary of information on the cores. Locations of cores are shown on Fig. 1B and 4. The cores have been described, interpreted and correlated to seismic data. The detailed analysis of cores comprised: sedimentological, grain size analysis, micropaleontologic description, physical parameters measurements (density, porosity, sonic velocities, magnetic susceptibility), clay analysis, palynological description (Beaudouin, Suc, Acherki, Courtois, Rabineau, Aloïsi, et al., 2003), and $C^{14}$ datings that have been corrected for reservoir age and transformed in calendar ages using Calib. 4.4 as developped and modified by Stuiver (Stuiver \& Reimer, 1993; Stuiver, Reimer, Bard, Beck, Burr, Hughen, et al., 1998a; Stuiver, Reimer \& Braziunas, 1998b) (Table 3).

\subsection{Stratigraphic modelling}

Two major types of models exist: stochastic models (that use probabilistic laws and therefore include a part of hazard in phenomenon) and deterministic models that consider that all event has a cause and that phenomena are reproducible. Deterministic models are based on physical equations. The model used here is Dionisos and was developed by the Institut Français du Pétrole (IFP) (Granjeon, 1997; Granjeon \& Joseph, 1999). It is a dynamic rule-based model in which equations are simplified and represent an average of different sedimentary processes. This dynamic-slope model uses a generalised diffusion (transport occurs in all direction but is proportional to slope) and advection equation (transport in one direction). The equation links sediment flux at each point within the basin to two principal parameters: local slope and water flow. Slope represent an amount of potential energy capable of moving fluid, water flow represents transport capacity and enables to define zones with higher transport (river belt for example). Slope and water flow are linked by the diffusion coefficient that characterises mean efficiency of transport for a given environment and changes in relation to the dynamic in action (fluvial, tidal, or wave dominated processes) (Granjeon, 1997; Granjeon \& Joseph, 1999).

$$
\begin{gathered}
Q=-\mathrm{K} \underbrace{\varphi_{\text {water }}}_{\begin{array}{c}
\text { transport } \\
\text { capacity }
\end{array}}) \cdot \underbrace{\frac{\partial \mathrm{h}}{\partial \mathrm{x}}}_{\text {energy }} \\
\text { with } \begin{cases}\mathrm{Q} & \text { sediment flow (in } \left.\mathrm{m}^{2} / \mathrm{s}\right) \\
\mathrm{K} & \text { diffusion coefficient (in } \left.\mathrm{m}^{2} / \mathrm{s}\right) \\
\varphi_{\text {water }} & \text { water flow (dimensionless) } \\
\mathrm{h} & \text { ground elevation (in } \mathrm{m})\end{cases} \\
\frac{\partial \mathrm{h}}{\partial \mathrm{x}} \quad \text { elevation gradient (slope) } \\
10
\end{gathered}
$$


The quantity of sediment deposited or eroded at each point is calculated by combining the diffusion equation and the principle of mass conservation:

$$
\frac{\partial h}{\partial t}=-\frac{\partial Q}{\partial x}
$$

Therefore when using several lithologies:

$$
\begin{gathered}
\vec{Q}_{i}=-v_{i} \cdot \mathrm{K}_{\mathrm{i}}\left(\varphi_{\text {water }}\right) \cdot \frac{\partial \mathrm{h}}{\partial \mathrm{x}} \\
\text { with } \mathrm{Q}_{\mathrm{i}} \text { lithology i flux }\left(\mathrm{m}^{2} / \mathrm{s}\right) \\
v_{\mathrm{i}} \text { lithology i content (dimensionless) } \\
\mathrm{K}_{\mathrm{i}} \text { diffusion coefficient related to lithology } \mathrm{i}\left(\mathrm{m}^{2} / \mathrm{s}\right) \\
\varphi_{\text {eau }} \quad \text { water flow (dimensionless) } \\
\mathrm{h} \text { ground elevation (m) } \\
\frac{\partial \mathrm{h}}{\partial \mathrm{x}}=\vec{\nabla} h \text { ground elevation gradient (slope) }
\end{gathered}
$$

Stratigraphic modeling is performed in order to reproduce observed geometries, test different hypothesis on strata formation and chronostratigraphic framework.

\section{Results and Geological interpretation}

\section{1- Present day shelf morphology and lithology}

A recent and detailed compilation of bathymetric data on the continental shelf and on the slope provides a very detailed image of the Gulf of Lion (Fig. 1) (Berné, Carré, Loubrieu, Mazé \& Normand, 2001). The shelf has a maximum width of $70 \mathrm{~km}$ in its western part, and is composed of three main physiographic domains. On the inner part, between the present coast and the $90 \mathrm{~m}$ isobath (around $30 \mathrm{~km}$ seaward of the coast), bathymetric contour lines are smooth and regularly spaced with an average slope of $0.3-0.45 \%$ (i.e. 0.17 $0.25^{\circ}$ ). They form bulges related to the subaqueous part (prodeltas) of previously described deltaic lobes. It is widely demonstrated that those deposits correspond to transgressive and high stand (post $18 \mathrm{kyr}^{14} \mathrm{C}$ ) sediments (Aloïsi, Got, Monaco \& Duboul-Razavet, 1973; Berné, Aloïsi, Baztan, Dennielou, Droz, Dos Reis, et al., 2002; Gensous \& Tesson, 1997; Gensous \& Tesson, 2003; Tesson, Gensous, Naudin, Chaignon \& Bresoli, 1998b). The outer part between 90 and $110 \mathrm{~m}$ is 20 to $40 \mathrm{~km}$ wide, with a very low-angle slope $0.05-0.25 \%\left(0.015-0.03^{\circ}\right)$. Bathymetric contour lines indicate an irregular 
morphology. Shallow cores (few meters long) indicate that sediments outcropping between 98-115 m are sands (Table2 and Fig. 4) (yellow colours in Fig. 1C and dots in Fig. 2). A clear step of up to $20 \mathrm{~m}$ height and dipping with an average slope of $6 \%\left(4^{\circ}\right)$ occurs on the outer shelf around $110 \mathrm{~m}$ in the western Gulf of Lion. The shelf break, defined by slopes reaching $1 \%\left(0.57^{\circ}\right)$, occurs between 110-120 m around the Aude-Hérault canyons and around 170$180 \mathrm{~m}$ on the Aude-Hérault interfluve. Between 120 and $160 \mathrm{~m}$ isobaths are again smooth on interfluves (with slopes around $0.4 \%$ ) and silty to muddy deposits (Fig. 1 and Fig. 2).

\section{2-Modern depositional profile and Holocene evolution of the Rhône delta}

A compilation of bathymetric and lithologic data around the Rhône river mouth enabled the drawing of the present day depositional profile of the Epicontinental Sedimentary Prism (ESP as defined by Aloïsi, 1986) (Fig. 5). The ESP is $40-50 \mathrm{~m}$ thick and lies at the Grand-Rhône river mouth with a fanshaped lobe that thins rapidly seawards (in $5 \mathrm{~km}$ ) (Fig. 5A). The ESP is developed from a source point (river dominated) but evolves to a lobate shape and even to a shore parallel mud dominated belt, because oceanographic processes (waves and currents) redistribute sediments (Fig. 2). Laterally, the depositional profile becomes rectilinear with a shoreface / offshore succession because sediment input is very much reduced to longshore transport due to wave action (Fig. 5B). The facies change downdip, from alluvial to littoral and delta front sands $(0-30 \mathrm{~m})$ to infralittoral silts and clays with black dots related to organic matter. From 0 to $30 \mathrm{~m}$ cores show a rhythmic alternation of sands and silty-clayey deposits that form an upward coarsening sequence (El Hmaidi, 1993); below $30 \mathrm{~m}$ deposits are made up of pelites $(4-7 \mu \mathrm{m})(>50 \%)$ (offshore deposits) (Fig. 2; Fig. 5 A and 5B).

The ESP developed at the mouth of the Rhône has migrated during recent time. L'Homer et al. (1981) described 3 major complexes related to a migration of the Rhône from West to East since the Maximum Flooding Surface. Recent work detailed the position and timing of the Rhône river and the subaerial lobes (Arnaud-Fassetta, 1998; Bruneton, Arnaud-Fassetta, Provansal \& Sistach, 2001; Provansal, Arnaud, Vella, Oberlin \& Sistach, 1998; Vella, 1999; Vella, Bourcier \& Provansal, 1998; Vella \& Lion", 2003). In the marine environment, Aloïsi mapped different delta lobes with at least 5 phases of construction limited to the northern part of the Gulf and related to transgressive and high stand relative sea level (Aloïsi, Monaco, Thommeret \& Thommeret, 1975c; Berné, et 
al., 2002; Gensous, Tesson \& Arnold, 1993a; Gensous, Williamson \& Tesson, 1993b; Labeyrie, Lalou, Monaco \& Thommeret, 1976). A recent study identified seven different lobes (Marsset \& Bellec, 2002). The average progradation of the Rhône delta during Late Holocene is about $15 \mathrm{~km}$. Depending on the dating of the Maximum Flooding Surface (8000 to 4000 yr. BP), according to recent versus older studies (respectively); average progradation rate of the coast therefore reaches 1800 to $3700 \mathrm{~m} \mathrm{kyr}^{-1}$ (Arnaud-Fassetta, et al., 1999; L'Homer, Bazile, Thommeret \& Thommeret, 1981; Pons, Toni \& Triat, 1979).

\section{4- Shelf sedimentary motif}

The analysis of reflection terminations (erosion truncation, onlap, downlap) and of reflection configuration (i.e. acoustic facies), allowed the identification of seismic units and their boundaries (U50 to U155) (Rabineau, 2001; Rabineau, et al., 1998). Geometry and thickness of individual units are shown on Fig. 7. Analysis of isobaths and isopachs maps (Fig. 7 and 9), seismic facies, 3D geometrical relationships between all the units and the overall architecture and stacking pattern all combine to define a basic depositional pattern. This basic depositional motif consists of a pair of horizontally juxtaposed prisms PI/PII capped by a major erosion surface named $\mathrm{D}_{\mathrm{i}}$ (Fig. 6). Prism PI has a low angle dipping clinoform facies $\left(<1^{\circ}\right)$. Prism PII has steeply dipping clinoform facies $\left(\sim 4^{\circ}\right)$. Prism PI lies on the middle shelf. Prism PII lies on the outer shelf between 40 and $70 \mathrm{~km}$ from the present day coastline. The surface between PI and PII is an erosion surface that truncates deposits of PI. A small Prism PIII (few meters thick), very discontinuous, appears on top of prism PII often in the form of dunes (Berné, et al., 1998a) (Fig. 6 and 8).

The motif PI/PII/(PIII) is repeated throughout the section, and at least five major erosion surfaces D30, D40, D50, D60, D70 can be identified on the profile P-1046 (Fig. 8). We call a sequence, deposits between two major discontinuities (cf. section 4.5 for sequence stratigraphy interpretation), the sequences are always made up of at least one PI and one PII. The three upper sequences (S3, S4, S5) clearly show the motif PI/PII/ (PIII) on profile P1046 (Fig. 8). Note that a sequence can be made up of several individual units, several prisms PI and/or several prisms PII (Fig. 7 and 8). For example the last sequence is composed of $\mathrm{PI}=\mathrm{U} 147$ and PII=U150s (with three units U150s-1, U150s-2 and U150s-3) and PI-U150m. In this case U150m is the seaward extension of prism PII (U150s). It is worth noting that this interpretation can not be based only on a single profile. For example, prisms PII of sequences S4 and S5 can not be seen on profile P- 
1046; a 3D analysis and interpretation of the stacking pattern is required to define a hierarchy between the units and identify major and secondary discontinuities. The 3D morphologies of those major surfaces are shown on the isobaths maps (Fig. 9). Note that our interpretation with 5 main sequences slightly differs from that of Tesson et al. (2000) who interpreted 6 main Regional Prograding Units for the same stratigraphic interval (Table 1).

\section{4- Facies and Environment interpretation}

Shallow cores sample the uppermost sequence S5 in units U147, U150s and U150m (Table 1, Fig. 7 and Fig. 10).

The low angle dipping clinoforms (prism PI, U150 m) that extends seaward of PII (U150s) were sampled by cores 93C12, CLKS08, 94klu141b, 94klu142 at depth between 126 and $132 \mathrm{~m}$ present water depth (Table 2). Core CLKS08 is a good representative of facies Si (Table 3 ) and shows a laminated grey facies with alternating silt and clay deposits (rich in organic matter and often bioturbated) and occasional beds (several $\mathrm{mm}$ ) of fine to very fine sands with an erosional base (facies $\mathrm{Si}$ ). The texture is fine grained with more than $70 \%$ silt, $20 \%$ clay (median $10 \mu \mathrm{m}$ ); more than $90 \%$ of grains are smaller than $40 \mu \mathrm{m}$. The mineral phase is dominated by angular quartz, feldspars and fine black micas. The organic phase is less than a millimeter with organic vegetal debris, a few foraminifers and ostracods.

PII' (U150m) is interpreted as a low energy environment below permanent wave base and is a prodeltaic-upper offshore environment where clay is deposited. The sand layers are interpreted as storm deposits where erosion of sand from the shoreline and delta front of PII are redistributed to the offshore. These deposits, therefore formed between the permanent wave base (more than $20 \mathrm{~m}$ water depth at present) and the storm wave base (about $50 \mathrm{~m}$ water depth).

-A detailed pollen analysis was performed in the Si facies of core 93C12. Pollens are typical of cold climate (from 452 to $280 \mathrm{~cm}$ ) with alternating phases of arid, cold climate (steppe) and more humid climate (with altitudinal and mesothermes elements) (Acherki, 1997; Beaudouin, et al., 2003). C14 dates enable to interpret this variation as the transition between the end of the Marine Isotopic Stage 3 (MIS 3) and the beginning of MIS 2.

Benthic Foraminifers observed at 390-400 cm (Uvigerina pergrina, Hyalinea baltica and various forms of Cassidulinidae Globigerina) and planctonic Foraminifers observed at the same level pachyderma (senestra), Globigerina glutinata) together 
with Pteropods indicate a clear glacial climate associated with a paleobathymetry in the order of 30-40 m (Bourdillon, 1994).

-The interval between 280 and $105 \mathrm{~cm}$ is characterised by a cold and dry climate with 16 species of Bryozoans including 4 boreal species and very little dinokysts, which characterize low sea levels. Facies Si was deposited during the Glacial Maximum (MIS 2).

-The interval between 105 and $18 \mathrm{~cm}$ shows a gradual increase in temperature at the time of deposition (Late glacial between 15-13 ka BP cal) (end of isotopic stage 2).

-At the top of the Core $(0-18 \mathrm{~cm})$ the sandy facies with many shells debris but also clays correspond to a phase of climate amelioration Holocene.

Distal cores (CLKS11, CLKS12 and MD992348: Fig. 10) in unit U150m (respectively at 157 and $300 \mathrm{~m}$ water depth) correspond facies $\mathrm{Cl}$ which is plastic muds with very fine grains (median at $6 \mu \mathrm{m}$ ): $40-45 \%$ clays and $55-60 \%$ silts (Table 3). No sand and no vertical facies variations are observed except the quantity of organic matter and annelid tubes (that can be concentrated in fine layers) (facies $\mathrm{Cl}$ ). The mineral phase is dominated by angular Quartz, Micas, $\mathrm{CaCO} 3$ and pyrite. The environment of facies $\mathrm{Cl}$ is therefore interpreted as a lower offshore environment with depth of more than $50 \mathrm{~m}$ (by analogy to modern profiles) with intense bioturbation. Detailed pollen analysis on core CLKS11 and core MD2348 also show 2 main pollen assemblages (Beaudouin, et al., 2003) (see her Fig. 8). At the base of th ecore, pollens indicate a cold glacial climate related to MIS 2 (over more than 16m within the core). At the upper top a clear warming and more humid climate is described and is correlated to Holocene period (Beaudouin, et al., 2003).

In a more landward position, low angle dipping clinoforms less than $1^{\circ}$ steep (prism PI of U147) were sampled landward of the sandy prism PII (core CLVK20 on Fig. 10 at 95m water depth). The core shows three main facies (Fig. 10).

-At the base $(125-230 \mathrm{~cm})$, Facies Si with alternating silt and clay with some sand layers (similar to previous description).

-Between 125 to $35 \mathrm{~cm}$ : a fining upward sandy unit (Sa) with coarse sands at the base with shell debris and pebble layers (subfacies cSa), passing gradually to more silt and clay, and finally at the top $(35-0 \mathrm{~cm})$ : a grey-beige silty mud $(\mathrm{Cl})$. Bioturbation is frequent in facies Si, the minerals are mainly Micas and Quartz with angular shape. The microfauna (> $125 \mu \mathrm{m})$ includes many Ostracodes, Lamellibranchia, Bryozoairs, benthic and planctonic Foraminifers, organic 
matter, pollens. The contact between the basal silty clay (Si) and the overlying sand (Sa) is sharp and erosive with rip-up mud clasts.

The deeper facies is similar to the facies described in PII' and is interpreted as a prodeltaic-upper offshore environment.

Preliminary pollen and Dinokystes analysis showed that samples from facies Si present typical steppic pollens (Artemisia and Hippophae rhammoides) and rare but typical Dinokystes of glacial period (Bitectatodinieum tepikiense. Dating at 172-175 m on Ostracods shows that prism PI of S5 is $39,710 \mathrm{yr}^{14}{ }^{14} \mathrm{C}$ (Fig. 10). This date is close to the limit of validity of the method and must therefore be used with caution. Analysis of Ostracods sampled at $172-175 \mathrm{~cm}$ in the core, show a typical Mediterranean and infralittoral fauna (80\%) and outer shelf species $(20 \%)$. Specimens are very well preserved so they are considered as autochthonous. Sea level was lower than present (around $\mathbf{- 6 0} \mathbf{~ m}$ ).

Two samples in facies Sa show more Dinokystes; the percentage of Pinus also increases revealing a greater distance from the coast. Climate is cold and dry (Artemisia, Poacaeae and Hippophae rhammoides) but sea level is higher (high amount of Dinokysts). Sample 5 also in facies Sa confirms this evolution with less steppic and more thermophiles elements and also more dinokysts. This sample reveals a higher sea level and temperate to temperate hot and humid conditions. A dating at $71 \mathrm{~cm}$ on a Mollusc Bivalve shell yields an age of 10, 875 year BP- ${ }^{14} \mathrm{C}$.

The last sample in facies $\mathrm{Cl}$ registers the disappearance of steppic elements and the development of thermophile elements with some evidence of human activities (land under cultivation) indicating very recent deposition. Dinokysts are diverse and numerous. Climate is temperate to temperate hot and humid. So, core CLVK20 registers isotopic stage MIS3 at the base; then there is a hiatus during all MIS2 taking the form of an erosion surface.

The transgressive phase with a ravinement surface and the deposition of reworked sands and highstand muddy sediments is well registered at the top of core CLVK20. Cores (CLKS08 and CLKS11) in a more distal location have only a thin layer of Holocene reworked sands.

Dates and pollen analysis from core 92K19, taken in similar landward position on the shelf (see position in Fig. 1), give the comparable results: core 92K19 sampled old deposits of MIS 3 and probably MIS5 (Beaudouin, et al., 2003).

Cores 93C9, 93C"b, 93C4 sampled on the outer shelf in the "sables du large" area, show well sorted homogeneous fine to medium (to coarse) sands: facies Sa. The median is 200-250 $\mu \mathrm{m}$; silt and clay represent less than 10\%: (Fig. 2, Fig. 4, Table 2, Table 3). Marine fauna is diverse (e.g. bivalves, gastropods, 
bryozoans, Ostracods and rare benthic foraminifers). Quartz grains are rounded with glauconite, and shell debris (bioclastic sand). We interpret facies Sa as related to a high energy, shallow marine environment above the permanent wave base. The question, with so short cores in the sand, is whether they sampled prism PIII or prism PII.

Detailed analysis of Foraminifers, in core C9 (at 175-188cm: Fig. 10), show species characteristic of both temperate and warm climate and cold species from the glacial maximum (Elphidium often broken, worned miliols) indicating a reworking of older sediments from glacial time (Bourdillon, 1994). The date on microfauna at 175-188 gives an age of 12,710 years C14 BP. The upper part of core C9 is, at least, younger than this age. The sand in C9 is transgressive but reworking older sands because of cold species observed.

Slopes of clinoforms from PII are high and reach $4^{\circ}$ on average. This value is within the wide range of beach-shoreface-offshore depositional profiles $\left(0.2^{\circ}\right.$ to $10^{\circ}$ ) quoted by (Einsele, 1992)). Isopach map of U150 and the clear step seen on the bathymetric map show the extension of PII, its elongate form, globally parallel to the isobaths and to the coast line (Fig. 1, 6 and 7). The slopes of internal reflections are consistently perpendicular to the elongation of the unit and parallel between them, which suggests a linear littoral dominated by swells. The top of PII is interpreted as a delta front/upper shoreface environment (0-10m).

The existence of beach rocks on top of the last prism PII is another argument in favour of a littoral deposit as this type of cementation happens in very shallow waters near zero bathymetry (Bernier, Berné, Rabineau \& Thollet, 2003). Each clinoform is interpreted as an internal surface of stratification related to lithological contrasts, it corresponds to a time line that represents the depositional profile at that time. The thickness of prism PII is about $25 \mathrm{~m}$ on the shelf and it progrades over a distance of about $15 \mathrm{~km}$.

Prism PII' (U150m) is clearly deposited during MIS2 and is in physical continuity with PII in the study area. We interpret Prism PII of S5 (U150s) as corresponding to the progradation of a delta-front/delta-slope/prodelta and laterally to the progradation of an upper-shoreface/shoreface/offshore profile with redistribution of sediments caused by wave action and littoral drift.

According to results shown above: Prism PI (U147) is deposited during MIS3. During MIS 2, prisms PII and PII' were deposited in a typical delta-frontprodelta-offshore depositional profile. The sand deposited above the erosion surface (prism PIII) is transgressive and results from erosion and redistribution of the regressive sand of prism PII. The very fine Holocene clay deposits with 
brown color (facies $\mathrm{Cl}$ ) indicate that only very little sediment reaches the outer shelf during high sea level.

\section{5 Sequence Stratigraphic interpretation and scenario of deposition}

The sedimentary motif PI/PII/ (PIII) can be interpreted as a forced regression deposit as defined by Plint, 1988; or Posamentier et al., 1992; also named the "falling stage systems tract" by Plint and Nummendal (2000). PI is deposited during a relatively high sea-level (MIS3). The lowering of sea-level between MIS 3 and MIS2 induces a rapid seaward shift of depositional environments, that results in a littoral, shoreface sandy deposit (PII) encased in offshore silts and clays (PI). Both PI and PII correspond to marine environments, the surface between PI and PII is a regressive surface of marine erosion, due to the action of waves and currents related to sea level drop between MIS3 and MIS 2. The transgressive surface of marine erosion and the ravinement surface are at the top of PII, between PII and PIII. The maximum flooding surface is at the top of PIII (Fig. 6B). The major erosion surface corresponds to the regressive surface of marine erosion related to sea level drop during LGM, to the subaerial surface of erosion at glacial maxima in some parts but also to the first transgressive surface (or flooding surface), to the ravinement surface formed during sea level rise and to the maximum flooading surface (MFS).

In summary, the uppermost sequence S5 mainly consists of shallow water wave dominated deltaic or shoreface facies that deposited since (at least) 40 ka (Fig. 11). Prism PI of S5 is deposited during MIS 3 (from 40 to $24 \mathrm{ka}$ ), prism PII and PII' of S5 correspond to deposition during sea level fall and lowstand of MIS 2 (between 24 and about $18 \mathrm{ka}$ ), whereas the thin PIII prism corresponds to deposition during the deglacial sea-level rise.

We propose the following scenario for the deposition of sediments in the Gulf of Lion during the last 100,000 years climatic cycle (Fig. 12). The sketch (Fig. 12) is based on observed geometries (described on seismic line 1049 see location on Fig. 5). High stand deposits (stage 5) accumulate on the inner shelf (Fig. 12a). As sea level is falling, previous deposits are eroded and new subunits are deposited seaward (Fig.12a, 12b, 12c). When sea level reaches its lowest value (Fig. 12d and 12e), the preserved part of earlier stages corresponds to the deepest environments (prodelta and offshore deposits) which have a low angle of deposition and correspond to prism PI. In this cycle, the last fall (just before stage 2 , around $26 \mathrm{ka}$ ) induces a rapid progradation of the shoreline and delta 
on the outer shelf (inset 12d, 12e), erosion of PI and the development of a downwardshift surface with prism PII downlapping PI. As to the existence of several prisms PI and PII in a major sequence as seen on seismic profiles, it is not clear if they are related to smaller scale global sea level variations within a climatic cycles or to sediment supply variations.

At the end of the sequence, the rapid rise of sea level (Fig. 12f, 12g) reworks only a small part of sand bodies (up to a few meters, with dunes formation: prism III). Finally, present day condition corresponds to high stand deposits that are concentrated on the inner shelf (inset $12 \mathrm{~h}$ ).

\section{6-Stratigraphic simulation: testing sequence duration}

Numerical models of stratigraphic simulation enable to test different geological scenario. In our study, it is mainly the sequence duration that needs to be tested. However, running numerical models needs a careful quantification of all input parameters: initial morphology, accommodation (sea level and subsidence), sediment flux at entry point, diffusion coefficients and erodability and bathymetric interval for environments. We also need to distinguish between well-known, less known and unknown parameters.

\subsubsection{Parameters quantification}

- Numerical models handle depositional environments using bathymetric intervals that need to be defined quantitatively. Synthesis on present day Rhône depositional profile (Fig. 5) together with description and interpretation of seismic and core data enabled us to give the depths and the slopes for the different depositional environments (Table 5).

- Initial morphology has been taken as a linear surface with a slope of $0.5 \mathrm{~m} / \mathrm{km}(0.05 \%)$ which corresponds to the average slope of the present day outer shelf.

- Accommodation can be determined in two ways: its physical origin defines it as the sum of eustasy and tectonics but it can also be calculated using the sedimentary record and adding thickness and paleobathymetry. In our study it is difficult to quantify paleobathymetries in details; on the contrary the period of time we are studying (Pleistocene) is rather well known concerning paleoclimate evolution and sea-level variations (thanks to isotopic studies in particular) compared to older sedimentary periods. Therefore we decided to quantify accommodation by estimating both eustatism and subsidence. Note that both eustatism and subsidence are functions of time. This time framework 
is the most unknown parameter. Therefore we decided to test several geological hypothesis that are exposed hereafter.

The amount of subsidence was estimated by assimilating erosion surfaces to lines, considering that they correspond to similar depositional depth and measuring the amount of tilt (in meters) between them (Fig. 14). Subsidence was taken as a tilt as that is very common on passive margins and shown on the seismic profiles by the progressive inclination of successive erosion surfaces in a seaward direction. The rate of subsidence is therefore variable in space but has been considered as constant through time at one position. However to obtain a rate of subsidence it is still necessary to have an estimation of the time span between two erosion surfaces. The variations in sea level were taken from the curve of Labeyrie (sea level derived from isotopic $\partial^{18} \mathrm{O}$ ) (Fig. 15) (Labeyrie, 1987).

- Sediment flux at entry point of the simulated profile is a difficult parameter to estimate, we used three different calculations:

Calculation 1: Previous work measured sedimentation rate as a function of distance from shoreline in the Rhône delta (Aloïsi, 1986, Fig. 3)). Approximating the sedimentation rate profile to an exponential function and integrating it as a function of distance gives the sediment flux at the Rhône mouth:

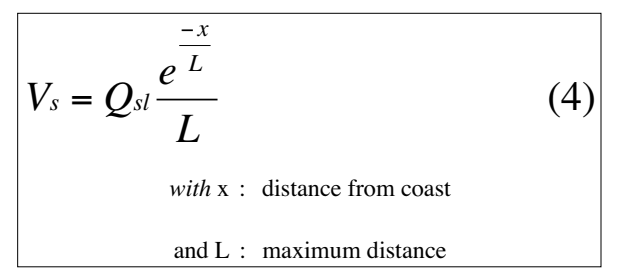

The result of this calculation is: $\mathrm{Qsl}=2500 \mathrm{~km}^{3} / \mathrm{Ma}$. It is the local mean flux at the Rhône's mouth during the time of deposition of the delta lobe.

Calculation 2: Total volume of sediments deposited on the entire Gulf for the last 12000 yr. was also estimated to be: $15010^{9} \mathrm{~m}^{3}$ (Aloïsi, 1986). Considering that all sediments come from one single point at the Rhône mouth this would correspond to a flux of $12000 \mathrm{~km}^{3} / \mathrm{Ma}$. Considering that the flux is equally distributed along the $150 \mathrm{~km}$ of the Gulf, the linear flux therefore equals 80 $\mathrm{km}^{3} / \mathrm{Ma}$. Both calculations correspond to end-members of estimation. Estimating that the Rhône provides $80 \%$ of all the sediment input (which is the case at present day), we calculate a Rhône flux of $9600 \mathrm{~km}^{3} / \mathrm{Ma}$ and distribute the remaining $2400 \mathrm{~km}^{3} / \mathrm{Ma}$ along the $120 \mathrm{~km}$-long coast of the Gulf, i.e. a linear flux of $20 \mathrm{~km}^{3} / \mathrm{Ma}$. 
Calculation 3: Analysis and interpretation of seismic data enables to quantify the amount of sediments within major sequences (between major discontinuities defined previously). The volume of sediments is calculated using the thicknesses and mapping the extension of units and sequences. To obtain sediment flux, we need to have the time span between discontinuities. Note that this calculation corresponds to a "sedimented flux", i. e. to the flux of sediment transported and trapped on the shelf; it does not take into account sediments coming from the river but escaping from the shelf and transported to the slope and deep basin.

Hypothesis 1: sequences are of very short duration, i.e. S3 corresponds to MIS 3: Qsl $=40 \mathrm{~km}^{3} / \mathrm{Ma}$

Hypothesis 2: sequences are of longer duration, i.e. S3 corresponds to MIS 8: Qsl $=4,5 \mathrm{~km}^{3} / \mathrm{Ma}$

Those calculations only give the order of magnitude of sediment flux. This parameter will be adjusted during the simulations.

- Erodability is another parameter difficult to quantify. Erosion on continents in drainage basins gives mean rates of 0,1 to $100 \mathrm{~m} / \mathrm{Ma}$ (Summerfield \& Hulton, 1994). In the Alps or in the Himalayas erosion can reach $1000 \mathrm{~m} / \mathrm{Ma}$ (Milliman, Yun-Shan, Mei-E \& Saito, 1987) to 3000 m/Ma (Galy, France-Lanord \& Derry, 1996) in relation with isostatic uplift. In this study, we also used a high value of erodability of $2500 \mathrm{~m} /$ Ma for sediments on the shelf, because the potential erosion of recently deposited sediments is higher than rocks and the erosion is due to both subaerial and submarine processes.

\subsubsection{Simulation results}

A serie of tests have been run through time to test the duration and the overall architecture of sequences. Thoses tests and the parameters used are summarized in Table 6.

\section{Test 1 and 2:}

The purpose of those runs is to test the ability of the model to reproduce correctly the present day depositional profile observed at the Rhône mouth and in a shoreface environment along the coast (compare Fig. 13 and Fig. 5)). Sea level was considered as constant and no subsidence was taken into account (Table 6). Our conclusion is that the model reproduces correctly the evolution of slope in depth through the different environments both in a deltaic context with high slope and high rate of progradation (Fig. 13A) and in a shoreface context with lower slope and lower rate of progradation (Fig. 13B). This allowed us to define the parameters governing the transport law (diffusion 
coefficients). Diffusion coefficients are similar in the two simulations, but the sediment flux was decreased by three in the second case because the main sediment flux comes from the Rhône river and decreases laterally in shoreface environments.

\section{Test 3,4 and 5 :}

The purpose of those runs is to reproduce the sedimentary motif PI/PII observed on the middle-outer shelf (about $50 \mathrm{~km}$ ).

The strategy was to run a suite of simulations using different time scales (different portions of the sea level curve) and compare the results to seismic data (trials and errors method). Fig. 15 shows the different runs. The subsidence rate ranges from $340 \mathrm{~m} / \mathrm{Ma}($ at $X=0)$ to $525 \mathrm{~m} / \mathrm{Ma}($ at $X=68 \mathrm{~km})$ in order to have enough space to deposit sediments.

Runs over $16 \mathrm{ka}$ (A, B) were unable to reproduce the observed motif whatever the amount of sediment at $X=0\left(15\right.$ to $\left.60 \mathrm{~km}^{3} / \mathrm{Ma}\right)$. In run $\left.\mathrm{C}\right)$ sediment flux is equal to $28 \mathrm{~km}^{3} / \mathrm{Ma}$. In this run, over $60 \mathrm{ka}$, the overall sedimentary motif PI/PII / (PIII) is well reproduced (compare Fig. 15C and Fig. 8). Results of stratigraphic simulations confirm our interpretation based on core and seismic data: PII is not transgressive, the motif PI/PII is related to, at least, the last $60 \mathrm{ka}$, PI is deposited during MIS3, PII-PII' during MIS2 and the transgressive deposits are very thin. PII is not transgressive. In details, we note that the top of prism PII is too deep (around $140 \mathrm{~m}$ ) on Fig. 15. This showed that the value taken for subsidence was too important.

\section{Test 6 and 7:}

The purpose of those runs is to reproduce several sequences and to better define subsidence. We used the standard SPECMAP reference curve (sea level derived from isotopic $\partial^{18} \mathrm{O}$ ) (Imbrie, Hays, Martinson, McIntyre, Mix, Morley, et al., 1984) as a proxy for sea level variations for the last 350 ka (Fig. 16-inset). The subsidence was taken as a tilt reaching only $250 \mathrm{~m} /$ Ma on the outer shelf. This quantitative value for subsidence rate has been validated by independent calculation of the same average rate of total subsidence for the entire Plioquaternary (240-260 m/Ma) at $70 \mathrm{~km}$ from the coast based on evidence of deeper penetration seismic profiles (Rabineau, 2001). The flux of sediments has been calibrated in several runs in order to fill the available place. The run showed in Figure 16 shows that the three sequences S3, S4, S5 observed on the seismic profiles are very well reproduced (compare with Fig. 7). Both thickness of sequences and position of prisms PI and PII are reproduced. Our conclusion is that S3, S4, S5 are associated, respectively, to MIS 8, MIS 6 
and MIS 2. Major sequences and discontinuities recorded in the western part of the Gulf of Lion are related to 100,000 years cyclicity with a record of successive glacial maxima.

The sediment flux used in this run was $6 \mathrm{~km}^{3} / \mathrm{Ma}$. Note that it is smaller than previous runs in (Fig. 15) where subsidence was also higher. However, this flux only represent a "shelf sedimented" sediment flux as we did not simulate any transport of sediments through canyons and deep sea environments where sedimentation is important, specially at glacial maxima (Baztan, Berné, Olivet, Rabineau, Aslanian, Gaudin, et al., 2003). Real sediment flux must be higher than this value. As for variations in sediment flux through time, and especially between glacial and interglacial periods (with three to five time the amount of sediments during glacial time), the runs showed that the overall geometry and stacking pattern did not change significantly.

Simulations using a much shorter sequence duration (20 ka) could not reproduce observed geometries of the PI/PII motif; such an interpretation would imply anyway, unacceptably rapid subsidence rates of the order of $2500 \mathrm{~m} /$ Ma which is unrealistic on passive margins.

In details, the run over $335 \mathrm{ka}$, also shows that several prisms PII can be observed within a single sequence (S4 and S5) for example and correspond (in the simulation) to higher order sea level variations (MIS 4 in S5 for example). It is of interest to notice that we had observed several of those prisms within the sequences (S4 and S5) in the seismic data (Fig. 8). So, the multiple units and prisms observed on seismic data could be related to higher order cyclicity within major 100,000 years climatic cycles.

\section{Conclusion}

The observed motif PI/PII seems strongly associated with 100,000 years climatic cycles and individual sequences can not be correlated with higher frequency cycles as previously suggested (Tesson, Allen \& Ravenne, 1993; Tesson, Posamentier \& Gensous, 2000). The basic depositional pattern in the western part of the Gulf of Lion records a 100000 years glacioeustatic (interglacial/glacial) cycle with an exceptional preservation of shoreline position at glacial maxima. At least the last five cycles are recorded on the outer shelf. Some higher order cyclicities may also be recorded within the motif but further work needs to be undertaken to analyse them. 


\section{Acknowledgements}

We would like to thank the captains and the crews of Ifremer R/V L'Atalante, Le Suroit, L' Europe, that provided invaluable assistance during several cruises in the Gulf of Lion.

This research was mainly funded by IFREMER. MR received a scholarship from IFREMER (Serge Berné), IFP (Christian Ravenne, Rémi Eschard) for her $\mathrm{PhD}$ at Rennes University (François Guillocheau). Additional support comes from the French GDR Marges (French "Margins" programme) and from the European Community through the Eurostrataform (EVK3-CT-2002-00079) and Promess 1 (EVR1-CT-2002-40024) projects.

M. Olagnon and Hervé Nouzé developed new modules on Sithere for this study, they are both warmly thanked.

J-P. Suc realized pollen analysis on 6 key levels on core CLVK20, J.P. Peypouquet realised analysis on Ostracodes and François Guichard helped with datation on this core.

C. Bourdillon realised the Foraminifers analysis on cores C9, C12

Fabienne Duval and Catherine Satra worked on arcview and provided maps in the area (Fig. 2 and 4).

\section{Tables Captions:}

Table 1: Presentation of successive interpretation from main authors and correlation of surfaces and units. Authors and interpretations are presented in four main groups of columns that represent principal steps and main divergence in the interpretation. (Group 1: Monaco, Got, Aloïsi et al.; Group 2: Tesson, Gensous, Chihi, El Hmaïdi et al.; Group 3: Torres et al.; Group 4: Rabineau, Berné et al.). In each group, both units and surfaces are presented. Surfaces are labelled in italic just below the wavy (erosional) surface. Units are detailed between surfaces. The last column of each group presents the chronostratigraphic interpretation of the group.

Table 2: Information on cores used in the study. All Cores are Kullenberg Cores except the cores with VK in their names that are Vibrocores (e. g. 97CLVK20). Cores with the same superscript have been sampled at the same location. Unit correspond to the seismic unit sampled by the core and based on seismic-core correlation. Coordinates are in WGS84. Bathymetry is present day depth of the top of the core in meters. Profile and time correspond to the exact position of the core on seismic data. 
Table 3: Facies described in shallow cores

Table 4: Datings on cores 92C12, 92K19, CLKS11, CLVK20, C9 with $\mathrm{C}^{14}$ ages and calibrated calendar ages, the reservoir age has been taken as an average of 400 years because of the variations in the evaluated reservoir age in the Gulf of Lion: 293 years (near Toulon); 467 near Banyuls and 587 near Sète (Siani, Paterne, Arnold, Bard, Métivier, Tisnerat, et al., 2000).

Table 5: Bathymetric limits and slopes of different sedimentary environments. The distinctin between lower offshore and open marine is purely formal and does not correspond to any specific criteria. Here, it is the bathymetric contour $60 \mathrm{~m}$.

Table 6: Summary of the different runs using numerical stratigraphic model DIONISOS.

\section{Figures Captions:}

Fig. 1. A) Location of the Gulf of Lion within the Western Mediterranean. B) Ifremer High Resolution Seismic profiles and cores data base. C) Bathymetric map of the Gulf of (in meters) (modified from Berné et al., 2002). From 0 to $120 \mathrm{~m}$ isobaths are represented every $2.5 \mathrm{~m}$. From $200 \mathrm{~m}$ downwards, isobaths are represented every $50 \mathrm{~m}$. The study area is localised with a black rectangle. Black lines represent seismic line drawings shown in Fig. 3B and depositional profiles in Fig. 5A and 5B. The main river is the Rhône to the North with its two distributaries (the Petit Rhône and the Grand Rhône). Note the lobate shape of isobaths on the shelf in front of the Rhône outlets, which corresponds to Late Quaternary the transgressive and high stand main depocenter. In the western part of the Gulf of Lion, rivers are smaller and do not create lobate morphologies on teh sea floor. From the shoreline to the deep sea, three main areas appear: a strip along the coast on the inner shelf with smooth isobaths $(0-90 \mathrm{~m}$, orange colours, zone I) (high stand wedge); on the outer shelf a flat area with rough bathymetric contour lines (90-110m, yellow colours, zone II) (low stand wedge); deeper than the shelf break (blue colours, zone III) the slope increases and canyons are distributed all along the slope. A: Aude (or Bourcart) canyon; $\mathrm{H}$ : Hérault canyon. The red triangle correspond to the location of piston core $92 \mathrm{~K} 19$ in $92 \mathrm{~m}$ of water depth.

Fig. 2. Morphosedimentary map based on previously published geological and sedimentological maps (Aloïsi, Got, Monaco \& DuboulRazavet, 1973), (Aloïsi, Got, Monaco \& Duboul-Razavet, ) showing the nature of outcropping sediments, bathymetry from Berné et al. 2002 with isobaths every $5 \mathrm{~m}$ on the shelf down to $200 \mathrm{~m}$ and every 
$100 \mathrm{~m}$ on the slope. A summary of main currents in the Gulf of Lion is also represented (from (Millot, 1990); (CSCF, 1984); (COB, 1981); (Suanez \& Provansal, 1998)). The general geostrophic circulation (Northern Current, NC) follows the slope to the Southwest; the small wellow loops on the shelf represent the surface drift related to Northeastern winds; coastal surface currents related to winds are shown with white and red arrows; small blue arrows represent littoral transport.

Fig. 3. Previous descriptions and interpretations of shelf deposits in the Gulf of Lion.

A): Aloïsi, 1986. Four erosion surfaces correlated to Würm IV, Würm III, Riss and Mindel major glaciations.

B): Tesson et al., 1993. At least 6 erosion surfaces correlated to distinct episodes of erosion within the Würm period $(100 \mathrm{ka})$. (See position of figure $3 \mathrm{~B}$ in Fig. 1).

Sequence correlation: S1=Top f; S2=Top e; S3=Top d; S4= Top c

C): Torres, 1995 Major units are correlated to Marine Isotopic Stages MIS1, MIS2, MIS6, MIS8, MIS10, MIS12, MIS14 and MIS16. (See also Table 1 for the correspondence of different nomenclature of units)

D) Tesson et al., 2000. Interpretating sketch explaining the deposition of one sequence. Note that the IU (intercalated units) are interpreted as deposited during transgression.

Fig. 4. Detailed study area, around the Aude-Hérault canyons, with a simplified bathymetry with a line every $50 \mathrm{~m}$, position of very high resolution seismic Sparker lines and position of cores (red triangles). Colours of lines correspond to different cruises. The grid of seismic lines has a spacing between 400 and $1500 \mathrm{~m}$. Cores used and presented in this article are labelled with their names.

Fig. 5. Present day depositional and lithological profiles from shoreline to offshore deposits from bathymetric data and core information (see position in Fig. 1C). Dots: sand; dots and dashed lines: silty sand; dashed lines: silt and clay; grey colour: clay

A) Present day fluvial dominated profile near the Rhône outlet showing delta front, prodelta to offshore deposits. Note the high angle of delta front-prodelta deposits and the lobate shape on the $3 \mathrm{D}$ view (inset modified from (Lafont, 1994); BFP, BFD : proximl and distal delta front ; GMB-MGF: lower offshore).

B) Wave dominated profile with lower dipping angles. Note the lower angle dipping profile and the linear shape of the shoreline on the $3 \mathrm{D}$ view (inset modified from (Lafont, 1994); PLB-PLH: beach; SHB: avantplage; OSP and OSD: proximal and distal upper offshore; MGF-lower offshore).

a, b, c : cores with sedimentation rate as measured by Aloïsi, 1986. 
The dashed lines through the depositional profiles represent time lines.

Fig. 6. Sedimentary motif observed on seismic lines. Two kinds of prisms are horizontally juxtaposed. Prism PI (in blue with low angle dipping reflections) landward, and prism PII seaward (in yellow with high angle dipping reflections) that truncates internal reflection of prism PI. Prism PII also has a seaward equivalent called PII' that has the same seismic facies as PI. On top of PII a small and thin unit with high angle or chaotic reflections (PIII) consists of transverse or longitudinal bedforms (Berné, et al., 1998a).

Fig. 7. Thickness maps (in milliseconds two way travel time, ms TWTT) of individual seismic units U75, U80, U85, U90, U100, U105, U110, U150. Color scales represent different thickness for each unit. The coordinates have been converted from geographic Lambert projection using Clarke 1880 ellipsoid to $\mathrm{XY}$.

Fig. 8. Seismic Profile 1046 (TWTT in $\mathrm{ms}$ ) showing the repetition of the motif in depth (position in Fig. 5). Three sequences (S3, S4, S5) of horizontally juxtaposed prisms PI/PII are stacked vertically. Conversion to depth in meters is approximate and has been done using a velocity of $1500 \mathrm{~m} / \mathrm{s}$ in waters (right scale) and $1800 \mathrm{~m} / \mathrm{s}$ in sediments (giving the $40 \mathrm{~m}$ thick reference).

Fig. 9. Isochron maps (in ms TWTT) of major discontinuities D70, D60, D50, D40 and D30 corresponding to the limits of seismic sequences. The coordinates have been converted from geographic Lambert projection using Clarke 1880 ellipsoid to XY.

Fig. 10. Lithology of key cores sampled within prisms PI, PII and PIII of Sequence S5 (position in Fig. 4 and projected on seismic profile Fig. $8)$.

Red stars display datings (transformed in calendar years see Table 2). Black dots indicate samples used for micropaleontological analysis. The thin lines represent time lines corresponding to isotopic stages terminations as dated by Martinson (Martinson, Pisias, Hays, Imbrie, Moore \& Shackleton, 1987) (numbers in the squares are in calendar years BP). The correlation lines have been established taking into account ${ }^{14} \mathrm{C}$ datings (transformed in calendar years), sedimentary facies, micro-palaeontology and pollen analysis. In circles : HST: High stand System Tract deposits; $\mathrm{T}$ : transgressive deposits; $\mathrm{T} 1$ early transgressive, T2 late transgressive; FRST: Forced Regressive System Tract deposits. 
Fig. 11. Line drawings of seismic line 1049 showing the last sequence S5 with horizontally juxtaposed prisms PI/PII and a small and discontinuous prism PIII on top. Surficial cores (black vertical bars) sampled the S5 sequence: detailed core analysis have enabled to correlate the upper units to sea level curve in time (calendar yr. BP, from Labeyrie, 1987) using radiocarbon datings, environments and bathymetric indicators. Sequence S5 corresponds to at least the last $50 \mathrm{ka}$.

Fig. 12. Scenario based on observed geometries for the deposition of the last 100,000 year sequence of paired prisms PI/PII (from MIS 5 to present) in the western area of the Gulf of Lion (profile P1061-1047 see position in Fig. 1). Depths are in meters. Section a represents the situation during MIS 5 with a high sea level when deposition occurs on the inner shelf. The red surface corresponds to major discontinuity D60. Subsidence has been taken into account in the form of a tilt of the shelf. Morphology of surface D60 is corrected from the effect of subsidence. Section a to e correspond to a global lowering of sea level, insets e to inset $h$ to a global rise in sea level. Individual smaller scale cycles are not presented. Colours enable to distinguish between different units, but do not represent sedimentary depositional environments. From sections a to c, sea level lowers and sediments are progressively eroded, only the toes of clinoforms are preserved and constitute prism PI (U147). Section d represents the the last fall, with deposition of high angle dipping clinoforms of prism PII (U150). Section e represent the situation at the last glacial maxima, PII has prograded to the outer shelf, the shoreline is at $70 \mathrm{~km}$ from present coastline. Note also the toes of high angle clinoforms that deepens through time (from 115 to $140 \mathrm{~m}$ ) which is a consequence of the lowering of sea level. During the beginning of relative sea level rise (section $\mathrm{f}$ ), the transgressive sediments are restricted to a thin veneer of reworked sandy materials on the outer shelf. Prism PII is preserved.

Fig. 13. Stratigraphic simulation using Dionisos software (IFP) showing the evolution of environments and dip angle with depth. These simulations were done to test the ability of the software to reproduce present day shoreline-offshore depositional profiles as observed in the field. Sea level is constant during simulation and no subsidence rate has been taken into account. $b(m)$ : water depths in meters. Diffusion coefficients are the same in the two simulations.

a) Deltaic profile simulation, sediment flux has been taken as 75 $\mathrm{k} \mathrm{m}^{3} / \mathrm{Ma}$

b) Shoreface profile simulation, sediment flux has been taken as 15 $\mathrm{k} \mathrm{m}^{3} / \mathrm{Ma}$ 
Note the good match with real profiles of the Gulf of Lion (compare with Fig. 5); note also the difference in progradation rates in $\mathrm{A}$ and $\mathrm{B}$. Maximum erosion rate of sediment is $1500 \mathrm{~m} / \mathrm{Ma}$.

Fig. 14. Quantification of key parameters for the simulation.

A) Estimation of subsidence: in grey: discontinuity seen on seismic profiles. In black: simplification of the surfaces to a line. The two surfaces represent the same paleogeography. The tilt, between the surfaces, corresponds to the total subsidence of the margin between D50 and the bottom that creates enough accommodation to deposit and preserve sediments.

B) Simplified initial morphology used at the beginning of the simulation: linear slope of $0.5 \mathrm{~m} \cdot \mathrm{km}^{-1}$, which corresponds to the average modern slope of the mid shelf.

C) Variation of sedimentation rate as an exponential function of distance from coast in the modern Rhône delta. The values (diamonds) are taken from Aloïsi (1986). The area under the curve corresponds to the inferred sediment flux from the Rhône that sedimented in the delta.

Fig. 15. Stratigraphic simulation using Dionisos software (developed by IFP). The three runs A), B) C) were done using the sea level curve from Labeyrie (1987); the subsidence rate has been taken as a tilt reaching $525 \mathrm{~m} . \mathrm{Ma}^{-1}$ at $70 \mathrm{~km}$ from the coast, the tilt has been taken constant through time (but not space). Depths are in meters. Maximum erosion rate is $2500 \mathrm{~m} \cdot \mathrm{Ma}^{-1}$. Time step is $1 \mathrm{ka}$.

A) The run is done over the last $16 \mathrm{ka}$, input sediment flux is 15 $\mathrm{k} \mathrm{m}{ }^{3} \cdot \mathrm{Ma}^{-1}$ at $\mathrm{X}=0$

B) The run is done over the last $16 \mathrm{ka}$, input sediment flux is 60 $\mathrm{k} \mathrm{m}^{3} \cdot \mathrm{Ma}^{-1}$ at $\mathrm{X}=0$

C) The run has been done for the last $59 \mathrm{ka}$, input sediment flux is 28 $\mathrm{k} \mathrm{m}^{3} / \mathrm{Ma}^{-1}$ at $\mathrm{X}=0$. Note the horizontally juxtaposed prisms PI (inner shelf) and PII (outer shelf) as described in observed data (compare to Fig.s 6 and 8). Prism PI is deposited during MIS 3, prism PII is deposited during MIS 2. Also note the variation in progradation rates during MIS 3 and MIS 2 due to erosion of previously deposited deposits of MIS 3 during sea level fall that contributes to the flux of sediment that feeds the littoral. Increased sediment flux combined to a reduced accommodation induces a clear increase in progradation rate.

Fig. 16. Stratigraphic simulation using Dionisos. The run corresponds to the last $335 \mathrm{ka}$ using the SPECMAP sea level curve (Imbrie et al., 1984). 
Subsidence rate has been taken as a tilt reaching $250 \mathrm{~m} \cdot \mathrm{Ma}^{-1}$ at $70 \mathrm{~km}$ from the coast, the tilt has been taken as constant through time. Maximum erosion rate is $2500 \mathrm{~m} \cdot \mathrm{Ma}^{-1}$, input sediment flux is 6 $\mathrm{k} \mathrm{m}^{3} \cdot \mathrm{Ma}^{-1}$ at $\mathrm{X}=0$. Note the vertically stacked sequences of PI/PII (S3, S4 and S5) corresponding to MIS8, MIS6 and MIS2. Compare this run to Fig. 6. This run supports the hypothesis that each sequence of paired prisms is related to 100,000 year climatic cycles.

\section{References}

Acherki, N. (1997). "Analyse palynologique de quatre carottes du golfe de Lion: application à la restitution de la végétation et du climat du midi de la France pendant le dernier cycle cliumatique et à la stratigraphie marine." Université de Montpellier 2, $146 \mathrm{p}$.

Alinat, J., Hinz, K. \& Leenhardt, O. (1970). Quelques profils en sondage sismique continu en Méditerranée occidentale. Revue de l'Institut Français du Pétrole, 25 305-326.

Aloïsi, J. C., Got, H., Monaco, A. \& Duboul-Razavet, C. (1973). Carte géologique du précontinent pyrénéo-languedocien au 1/ 250 000, Musée Océanographique de Monaco.

Aloïsi, J. C., Got, H., Monaco, A. \& Duboul-Razavet, C. (1973). Carte géologique du précontinent languedocien au 1/250 000, du Cap Leucate à la pointe de Beauduc, Musée Océanographique de Monaco.

Aloïsi, J. C., Monaco, A., Thommeret, J. \& Thommeret, Y. (1975c). Evolution paléogéographique du plateau continental languedocien dans le cadre du golfe du Lion; Analyse comparée des données sismiques, sédimentologiques et radiométriques concernant le Quaternaire récent. Revue de Geographie Physique et de Geologie Dynamique, 17 (1), 13-22.

Aloïsi, J. C. (1986). "Sur un modèle de sédimentation deltaïque: contribution à la connaissance des marges passive." Thèse de Doctorat d'Etat, Université de Perpignan, $162 \mathrm{p}$.

Arnaud-Fassetta, G. (1998). “Dynamiques fluviales holocenes dans le delta du Rhône." Thèse de Doctorat, Université de Provence (Aix-Marseille I), 329 p.

Arnaud-Fassetta, G., Bruzzi, C., L'Homer, A., Provansal, M., Sabatier, F., Suanez, S. \& Vella, C. (1999). Géomorphologie du delta du Rhône: édification holocène et fonctionnement actuel. Livret-guide de l'excursion FrancoRoumaine du 23-24-25 Septembre 1999, CEREGE, Aix-Marseille, 105 p. 
Baztan, J., Berné, S., Olivet, J.-L., Rabineau, M., Aslanian, D., Gaudin, M., Réhault, J. P. \& Canals, M. (2003). The axial incision : the key to understand canyon evolution (in the western Gulf of Lions). Marine and Petroleum Geology, this issue.

Beaudouin, C., Suc, J.-P., Acherki, N., Courtois, L., Rabineau, M., Aloïsi, J. C., Sierro, F. J. \& Oberlin, C. (2003). OIS 5 to OIS 1 palynological record on the northwestern Mediterranean Shelf (Gulf of Lions). Marine and Petroleum Geology, this issue.

Berné, S., Lericolais, G., Marsset, T., Bourillet, J. F. \& de Batist, M. (1998a). Erosional shelf sand ridges and lowstand shorefaces: examples from tide and wave dominated environments of France. Journal of Sedimentary Research, 68 (4), 540-555.

Berné, S., Carré, D., Loubrieu, B., Mazé, J.-P. \& Normand, A. (2001). Carte morphobathymétrique du Golfe du Lion à l' échelle 1/100 000 ème. Brest, IFREMER et Région Languedoc Roussillon.

Berné, S., Aloïsi, J. C., Baztan, J., Dennielou, B., Droz, L., Dos Reis, T., Lofi, J., Méar, Y. \& Rabineau, M. (2002). Notice de la carte morpho-bathymétrique du Golfe du Lion. Brest, IFREMER et Région Languedoc Roussillon. 1: 48.

Bernier, P., Berné, S., Rabineau, M. \& Thollet, G. (2003). Last Glacial Maximum shoreline position in the Gulf of Lions (NW Mediterranean Sea) determined by lithified coastal sediments. Marine and Petroleum Geology, this volume.

Bourcart, J. (1947). Sur les rechs, sillons sous-marins du Plateau Continental des Albères (Pyrénées-Orientales). C.R.A.S., 224 (16), 1175-1177.

Bourcart, J. (1948). Sur la géologie sous-marine du Rech Lacaze-Duthiers, canon sous-marin du Roussillon. Comptes Rendus Hebdomadaires des seances de l'Académie des Sciences de Paris, 226 (22), 1827-1829.

Bourcart, J. (1956 b). Problèmes de Géologie Sous-marine. Paris: Masson, 124

Bourdillon, C. (1994). Micropaléontologie de sédiments de sondage dans le Golfe du Lion (mer Méditerranée), BRGM internal report N1864, 15 p.

Boutan, L. (1893). La photographie sous-marine. Archives de Zoologie Expérimentale, 3 (1), 281-324.

Bruneton, H., Arnaud-Fassetta, G., Provansal, M. \& Sistach, D. (2001). Geomorphological evidence for fluvial change during the Roman period in the lower Rhone Valley (southern France). Catena, 45 287-312.

Bruzzi, C. (1998). "Les tempêtes et l'évolution morphosédimentaire des plages orientales du delta du Rhône." Thèse de Doctorat, Université de Provence, AixMarseille, $326 \mathrm{p}$.

Chiocci, F. L., Ercilla, G. \& Torres, J. (1997). Stratal architecture of western Mediterranean margins as the result of the stacking of Quaternary lowstand 
deposits below glacio-eustatic fluctuation base level. Sedimentary Geology, 112 (3-4), 195-217.

COB (1981). Le littoral à grands traits- Façade Nº7 (Méditerranée). In: Synthèse des travaux de surveillance 1975-1979 du Réseau National d'Observation de la Qualité du Milieu. C. O. d. Bretagne. CNEXO-Ministère de l'environnement. Brest: 41176.

Cross, T. A. (1988). Controls on coal distribution in trangressive-regressive cycles, Upper Cretaceous, Western Interior, U.S.A. In: Sea-level changes - an integrated approach. Sec. Publ. Soc. Econ. Paleontol. Meneral. 42: 371-380.

Cross, T. A., Baker, M. A., Chapin, M. S., Clark, M. S., Gardner, M. H., Hanson, M. S., Lessenger, M. A., Little, L. D., McDonough, K. J., Sonnenfeld, M. D., Valasek, D. W., Williams, M. R. \& Witter, D. N. (1993). Applications of highresolution sequence stratigraphy to reservoir analysis. In: Subsurface reservoir characterization from outcrop observations. R. Eschard and B. Doligez. Technip. Paris: 11-33.

CSCF, (1984). Catalogue sédimentologique des côtes françaises : côtes de la Méditerranée de la frontière espagnole à la frontière italienne. Collections de la direction des études et recherches d'élecricité de France. Ministère des transports. Paris: $290 \mathrm{p}$.

Delesse (1871). Lithologie du fond des mers,

Einsele, G. (1992). Coastal and shallow sea sediments (including carbonates). In: Sedimentary Basins. Evolution, Facies and Sediment budget. G. Einsele. Springer-Verlag. Berlin, Heidelberg, New-York: 94-160.

El Hmaidi, A. (1993). "Unités sédimentaires et paléoenvironnements du Quaternaire terminal sur la marge rhodanienne (Golfe du Lion, France)." Thèse de Doctorat, Université de Perpignan, 178 p.

Galloway, W. E. (1989). Genetic stratigraphic sequences in basin analysis I: architecture and genesis of flooding surface bounded depositional units. American Association of Petroleum Geologists Bulletin, 73 125-142.

Galy, A., France-Lanord, C. \& Derry, L. A. (1996). The Late Oligocene-Early Miocene Himalayan belt Constraints deduced from isotopic compositions of Early Miocene turbidites in the Bengal Fan. Tectonophysics, 260 109-118.

Gensous, B., Tesson, M. \& Arnold, M. (1993a). Analyse en stratigraphie séquentielle des dépôts pléistocènes de la plateforme orientale du Rhône (France): confrontation de l'analyse sismique et des données de terrain. C. $R$. Acad. Sci. Paris, 317 803-810.

Gensous, B., Williamson, D. \& Tesson, M. (1993b). Late-Quaternary transgressive and highstand deposits of a deltaic shelf (Rhône delta, France). In: Sequence stratigraphy and facies associations. H. W. Posamentier, C. P. 
Summerhayes, B. A. Haq and G. P. Allen. International Association of Sedimentologists Spec. Pub. 18, Blackwell. Oxford: 197-212.

Gensous, B. \& Tesson, M. (1997). Les depots postglaciaires de la plate-forme rhodanienne; organisation stratigraphique et conditions de mise en place. Comptes Rendus de l'Academie des Sciences, Serie II, Sciences de la Terre et des Planetes. 325 (9), Pages 695-701.

Gensous, B. \& Tesson, M. (2003). L'analyse des dépôts postglaciaires et son application à l'étude des séquences de dépôt du Quaternaire terminal sur la plate-forme au large du Rhône (golfe du Lion). Bulletin de la Société Géologique de France, 174 (4), 401-419.

Got, H., Monaco, A. \& Reyss, D. (1969). Les canyons sous-marins de la mer Catalane, le rech du Cap et le rech Lacaze-Duthiers. II-Topographie de détail et carte sédimentologique. Vie et Milieu, Série B Océanographie, XX (2-B), 257-278.

Got, H. (1973). "Etude des corrélations tectonique-sédimentation au cours de l'histoire quaternaire du précontinent pyrénéo-catalan." Thèse de Doctorat d'Etat, Université de Perpignan, 294 p.

Granjeon, D. (1997). “Modélisation stratigraphique déterministe : conception et applications d'un modèle diffusif 3D multilithologique." Thèse de Doctorat, Université de Rennes 1, 175 p.

Granjeon, D. \& Joseph, P. (1999). Concepts and applications of a 3D multiple lithology, diffusive model in stratigraphic modeling. In: Numerical Experiments in Stratigraphy: Recent Advances in Stratigraphic and Sedimentologic Computer Simulations. SEPM (Society for Sedimentary Geology) Special Publications No. 62. Tulsa: 197-210.

Guillocheau, F. (1990). “Stratigraphie séquentielle des bassins de plate-forme : l'exemple Dévonien Armoricain." Louis Pasteur Strasbourg, 257 p.

Guillocheau, F. (1991). Modalités d'empilement des séquences génétiques dans un bassin de plate-forme (Dévonien Armoricain) : nature et distorsion des différents ordres de séquences de dépôts emboîtées. Bull. Centres Rech. Explor.Prod. Elf-Aquitaine, 15 (2), 383-410.

Hernandez-Molina, F. J., Somoza, L. \& Lobo, F. (2000). Seismic stratigraphy of the Gulf of Cadiz continental shelf: a model for late Quaternary very high resolution sequence stratigraphy. In: Sedimentary Responses to Forced Regressions. D. Hunt and R. Gawthorpe. Geological Society Special Publication. London 172: 329-362.

Homewood, P., Guillocheau, F., Eschard, R. \& Cross, T. A. (1992). Corrélations haute résolution et stratigraphie génétique: une démarche intégrée. Bull. Centres Rech. Explor.-Prod. Elf-Aquitaine, 16 (2), 357-381. 
Hunt, D. \& Tucker, M. E. (1992). Stranded parasequences and the forced regressive wedge systems tract: deposition during base-level fall. Sedimentary Geology, 81 1-9.

Imbrie, J., Hays, J. D., Martinson, D. G., McIntyre, A., Mix, A. C., Morley, J. J., Pisias, N. G., Prell, W. L. \& Shackleton, N. J. (1984). The orbital theory of Pleistocene climate: support from a revised chronology of the marine $\delta \mathrm{O}^{18}$ record. In: Milankovitch and climate. A. Berger, Imbrie, J., Hays, J., Kukla, G., Saltzman, B. Kluwer Academic Publishers. Hingham, Mass. 126: 269-305.

Jervey, M. T. (1988). Quantitative geological modelling of siliclastic rock sequences and their seismic expressions. In: Sea-level changes: an integrated approach. C. K. Wilgus, B. S. Hastings, C. G. St Kendall, C. A. Ross and J. C. Van Wagoner. SEPM Special Publication. Tulsa 42: 47-69.

L'Homer, A., Bazile, F., Thommeret, J. \& Thommeret, Y. (1981). Principales étapes de l'édification du delta du Rhône de $7000 \mathrm{BP}$ à nos jours; variations du niveau marin. Oceanis, 7 (4), 389-408.

Labeyrie, J., Lalou, C., Monaco, A. \& Thommeret, J. (1976). Chronologie des niveaux eustatiques sur la côte du Roussillon de -33000 ans B.P. à nos jours. Comptes Rendus de l'Académie des Sciences de Paris, 282 349-352.

Labeyrie, L. D. (1987). Variations in mode of formation and temperature of oceanic deep waters over the past 125,000 years. Nature, 327 (6122), 477-482.

Lafont, F. (1994). “Influences relatives de la subsidence et de l'eustatisme sur la localisation et la géométrie des réservoirs d'un système deltaïque. Exemple de l'Eocene du Bassin de Jaca (Pyrénées espagnoles)." Thèse de Doctorat, Université de Rennes 1, Mémoires Géosciences Rennes, 270 p.

Lagaaij, R. \& Kopstein, F. P. H. (1964). Typical features of a fluviomarine offlap sequence. In: Deltaic and shallow marine deposits. L. M. J. Van Straaten. Elsevier Pub. Co. Amsterdam: 216-226.

Lericolais, G., Girault, R., Tofani, R. \& Olagnon, M. (1991). Recent Advances in Shallow Seismic Reflection Processing. In:23rd Ocean Technology Conference, Houston, USA, (501-507), Annual meetin Proceedings.

Lericolais, G., Olagnon, M. \& Berné, S. (1994a). Use of fast simple migration processing for very high resolution seismic data. In:56th meeting of European Association of exploration Geophysicists, Vienna, Austria.

Lericolais, G., Olagnon, M., Krone, R. \& Nouzé, H. (1994b). Multiple removal in very high resolution seismic site survey data. In:Behaviour of offshore structures, Boston, USA, (125-136), Pergamon.

Lombard, A. (1956). Géologie Sédimentaire : Les séries marines. Paris: Masson, 722 
Marsset, T. \& Bellec, V. (2002). Late Pleistocene-Holocene deposits of the Rhône inner continental shelf (France): detailed mapping and correlation with previous continental and marine studies. Sedimentology, 49 255-276.

Martinson, D. G., Pisias, N. G., Hays, J. D., Imbrie, J., Moore, T. C., Jr. \& Shackleton, N. J. (1987). Age dating and the orbital theory of the ice ages: development of a high-resolution 0 to 300,000-year chronostratigraphy. Quaternary Research, 27 1-29.

Milliman, J. D., Yun-Shan, Q., Mei-E, R. \& Saito, Y. (1987). Man's influence on the erosion and transport of sediment by asian rivers : th eYellow river (Huanghe) example. Journal of Geology, 95 (751-762).

Millot, C. (1990). The Gulf of Lions' hydrodynamics. Continental Shelf Research, 10 (9-11), 885-894.

Mitchum, R. M. \& Van Wagoner, J. C. (1991). High-frequency sequences and their stacking patterns: sequence-stratigraphic evidence of high-frequency eustatic cycles. Sedimentary Geology, 70 131-160.

Monaco, A. (1971). “Contribution à l'étude géologique et sédimentologique du plateau continental du Roussillon." Thèse de Doctorat d'Etat, Université de Perpignan, $295 \mathrm{p}$.

Nouzé, H. (1993). Intégration de nouveaux modules de traitement de sismique très haute résolution dans Sithere., IFREMER, $\mathrm{p}$.

Oomkens, E. (1967). Depositional sequences and sand distribution in a deltaic complex; a sedimentological investigation of the post-glacial Rhone delta complex. Geologie en Mijnbouw, 46 (7), Pages 265-278.

Oomkens, E. (1970). Depositional Sequences and Sand Distribution in the Postglacial Rhône Delta Complex. In: Deltaic Sedimentation. Modern and Ancient. J. P. Morgan and R. H. Shaver. SEPM (Society for Sedimentary Geology) Special Publication $\mathrm{N}^{\circ} 15$. Tulsa, Oklahoma: 198-212.

Pauc, H. (1970). "Contribution à l'étude dynamique et structurale des suspensions solides au large du Grand Rhône (Crau de Roustan)." Thèse de 3ème cycle, Université de Toulouse Paul Sabatier, 126 p.

Payton, C. E. (1977). Seismic stratigraphy - applications to hydrocarbon exploitation. Tulsa, Oklahoma: Amer. Assoc. Petroleum Geol. Memoir 26, 516

Piper, D. J. W. \& Aksu, A. E. (1992). Architecture of stacked Quaternary deltas correlated to global oxygen isotopic curve. Geology, 20 415-418.

Plint, A. G. (1988). Sharp-based shoreface sequences and "offshore bars" in the Cardium Formation of Alberta: their relationship to relative changes in sea level. In: Sea-level changes: an integrated approach. C. K. Wilgus, B. S. Hastings, C. G. S. C. Kendall, H. W. Posamentier, C. A. Ross and J. C. Van Wagoner. SEPM Special Publication No. 42. Tulsa: 357-370. 
Plint, G. \& Nummendal, D. (2000). The falling stage systems tract: recognition and importance in sequence stratigraphic analysis. In: Sedimentary Responses to Foreced Regressions. D. Hunt and R. L. Gawthorpe. Geological Society of London. London 172: 1-17.

Pons, A., Toni, C. L. \& Triat, H. (1979). Edification de la Camargue et histoire holocène de sa végétation. Terre et vie, Rev. Ecol., 2 13-30.

Posamentier, H. W., Jervey, M. T. \& Vail, P. R. (1988a). Eustatic controls on clastic deposition I. Conceptual framework. In: Sea-Level Changes- an Integrated Approach. C. K. Wilgus, B. S. Hastings, C. G. S. C. Kendall, H. W. Posamentier, C. A. Ross and J. C. Van Wagoner. SEPM Spec. Pub. 42. Tulsa: 102-124.

Posamentier, H. W. \& Vail, P. R. (1988b). Eustatic controls on clastic deposition II. Sequences and system tract models. In: Sea-Level Changes- an Integrated Approach. C. K. Wilgus, B. S. Hastings, C. G. S. C. Kendall, H. W. Posamentier, C. A. Ross and J. C. Van Wagoner. SEPM Spec. Pub. 42. Tulsa: 125-154.

Posamentier, H. W., Allen, G. P., James, D. P. \& Tesson, M. (1992). Forced regressions in a sequence stratigraphic framework: concepts, examples and exploration significance. American Association of Petroleum Geologists Bulletin, 76 1687-1709.

Provansal, M., Arnaud, P. M., Vella, C., Oberlin, C. \& Sistach, D. (1998). Les sédiments de l'étang de Berre (Provence, France), témoins de la mobilité du niveau marin Holocène. Bulletin de la Societe Geologique de France, 169 (1), 127135.

Rabineau, M., Berné, S., Ledrezen, E., Lericolais, G., Marsset, T. \& Rotunno, M. (1998). 3D architecture of lowstand and transgressive Quaternary sand bodies on the outer shelf of the Gulf of Lion, France. Marine and Petroleum Geology, 15 439-452.

Rabineau, M. (2001). “Un modèle géométrique et stratigraphique des séquences de dépôts quaternaires de la plate-forme du Golfe du Lion : enregistrement des cycles glacioeustatiques de 100000 ans." Thèse de Doctorat, Université de Rennes 1 and IFREMER, $445 \mathrm{p}$.

Reyss, D. (1969). Les canyons sous-marins de la mer catalane, le rech du Cap et le rech Lacaze-Duthiers. I- Bathymétrie et topographie. Vie et Milieu, 20 (1B), 1336.

Siani, G., Paterne, M., Arnold, M., Bard, E., Métivier, B., Tisnerat, N. \& Bassinot, F. (2000). Radiocarbon reservoir ages in the Mediterranean Sea and Black Sea. Radiocarbon, 42 271-280.

Somoza, L., Hernandez-Molina, F. J., De Andres, J. R. \& Rey, J. (1997). Continental shelf architecture and sea-level cycles: Late Quaternary high- 
resolution stratigraphy of the Gulf of Cadiz, Spain. Geo-Marine Letters, 17 133139.

Stuiver, M. \& Reimer, P. (1993). Extended (super14)C data base and revised CALIB 3.0 (super 14)C age calibration program. Radiocarbon, 35 (1), 215-230.

Stuiver, M., Reimer, P. J., Bard, E., Beck, W. E., Burr, G. S., Hughen, K. A., Kromer, B., McCormac, F. G., v.d. Plicht, J. \& Spurk, M. (1998a). INTCAL98 radiocarbon age calibration 0-24,000 BP. Radiocarbon, 40 1041-1083.

Stuiver, M., Reimer, P. J. \& Braziunas, T. F. (1998b). High-precision radiocarbon age calibration for terrestrial and marine samples. Radiocarbon, 40 1127-1151.

Suanez, S. \& Provansal, M. (1998). Large scale evolution of the littoral of the Rhone Delta (southeast France). Journal of Coastal Research, 14 (2), Pages 493-501. Summerfield, M. A. \& Hulton, N. J. (1994). Natural controls of fluvial denudation rates in major world drainage basins. Journal of Geophysical Research, 99 (B7), 13871-13883.

Tesson, M., Ravenne, C. \& Allen, G. P. (1989). Application des principes de l'analyse en stratigraphie séquentielle aux prismes de bas niveau marin sur la plate-forme rhodanienne. Strata, 5 55-57.

Tesson, M., Ravenne, C. \& Allen, G. P. (1990a). Application des concepts de stratigraphie séquentielle à un profil sismique haute résolution transverse à la plate-forme rhôdanienne. Comptes Rendus de l'Académie des Sciences de Paris, 310 (II), 565-570.

Tesson, M., Gensous, B., Allen, G. P. \& Ravenne, C. (1990b). Late Quaternary lowstand wedges on the Rhône Continental Shelf, France. Marine Geology, 91 325-332.

Tesson, M., Allen, G. P. \& Ravenne, C. (1993). Late Pleistocene shelf-perched lowstand wedges on the Rhône continental shelf. In: Sequence stratigraphy and facies associations. H. W. Posamentier, C. P. Summerhayes, B. A. Haq and G. P. Allen. IAS Spec. Pub. 18, Blackwell Sci. Pub. Oxford: 183-196.

Tesson, M. \& Allen, G. (1995). Contrôle tectonique et eustatique haute fréquence de l'architecture et de la stratigraphie de dépôts de plate-forme péricratonique. Exemple du golfe du Lion (Méditerranée, France) et des dépôts quaternaires. C.R. Acad. Sci. Paris, 320 (série IIa), 39-46.

Tesson, M., Gensous, B., Naudin, J.-J., Chaignon, V. \& Bresoli, J. (1998b). Carte morpho-bathymétrique de la plate-forme du Golfe du Lion : un outil pour la reconnaissance et l'analyse des modifications environnementales récentes. Comptes Rendus de l'Académie des Sciences de Paris, 327 541-547.

Tesson, M., Posamentier, H. \& Gensous, B. (2000). Stratigraphic organisation of Late Pleistocene deposits of the western part of the Rhone shelf (Languedoc 
shelf) from high resolution seismic and core data. American Association of Petroleum Geologists Bulletin, 84 (1), 119-150.

Torres, J. (1995). “Analyse détaillée du transfert de sédiment du continent vers le bassin: le Quaternaire terminal au large du delta du Rhône (Méditerranée nord-occidentale)." Thèse de doctorat, Bretagne occidentale, 353 p.

Torres, J., Savoye, B. \& Cochonat, P. (1995b). The effects of Late Quaternary sealevel changes on the Rhône slope sedimentation (northwestern Mediterranean), as indicated by seismic stratigraphy. Journal of Sedimentary Research, B65 (3), 368-387.

Trincardi, F. \& Correggiari, A. (2000). Quaternary forced-regression deposits in the Adriatic Basin and the record of composite sea-level cycles. In: Sedimentary responses to forced regressions. D. Hunt and R. Gawthorpe. Geological Society Special Publication. London 134.

Vail, P. R., Colin, J. P., Du Chene, R. J., Kuchly, J., Mediavilla, F. \& Trifilieff, V. (1987). La stratigraphie séquentielle et son application aux corrélations chronostratigraphiques dans le Jurassique du Bassin de Paris. Bull. Soc. Géol. France, 8 (7), 1301-1321.

Vella, C., Bourcier, M. \& Provansal, M. (1998). Montée du niveau marin et sédimentation Holocène sur la marge orientale du delta du Rhône, Provence, France. Bulletin de la Société géologique de France, 169 (3), 403-414.

Vella, C. (1999). "Perception et évaluation de lamobilité du littoral holocène sur lamarge orientale du delta du Rhône." Thèse de Doctorat, Université de Provence, Aix-Marseille I, $225 \mathrm{p}$.

Vella, C. \& Lion", M. G. m. G. d. (2003). Corrélations terre/mer sur le delta du Rhône dans le Golfe du Lion. Bulletin du GDR Marges. http://gdrmarges.lgs.jussieu.fr/Bulletin5-GDR.pdf: p. 15-17. 
A)

$3^{\circ} 00 \quad 4^{\circ} 00 \quad 5^{\circ} 00$

B)
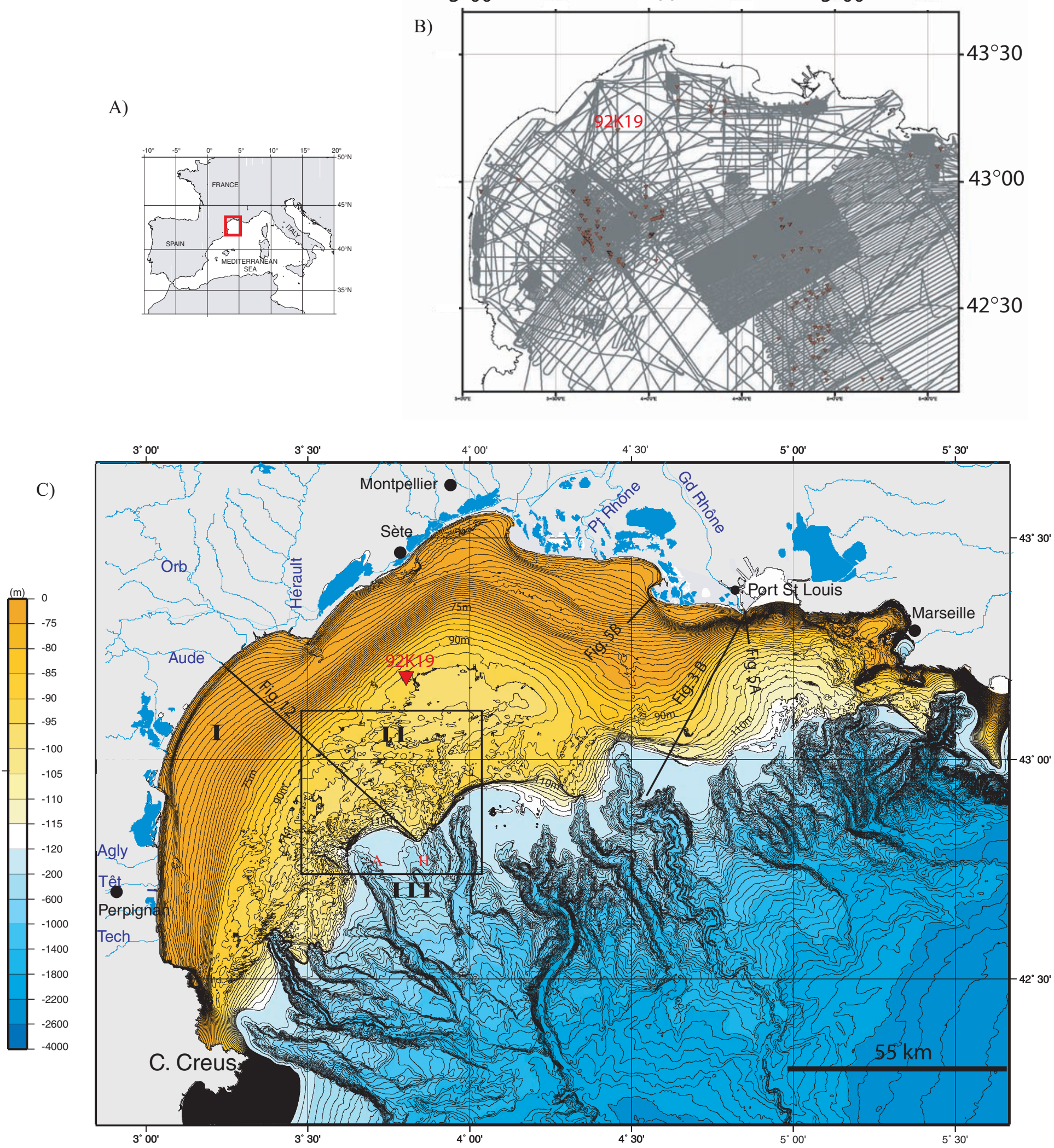

Rabineau et al., Figure 1 


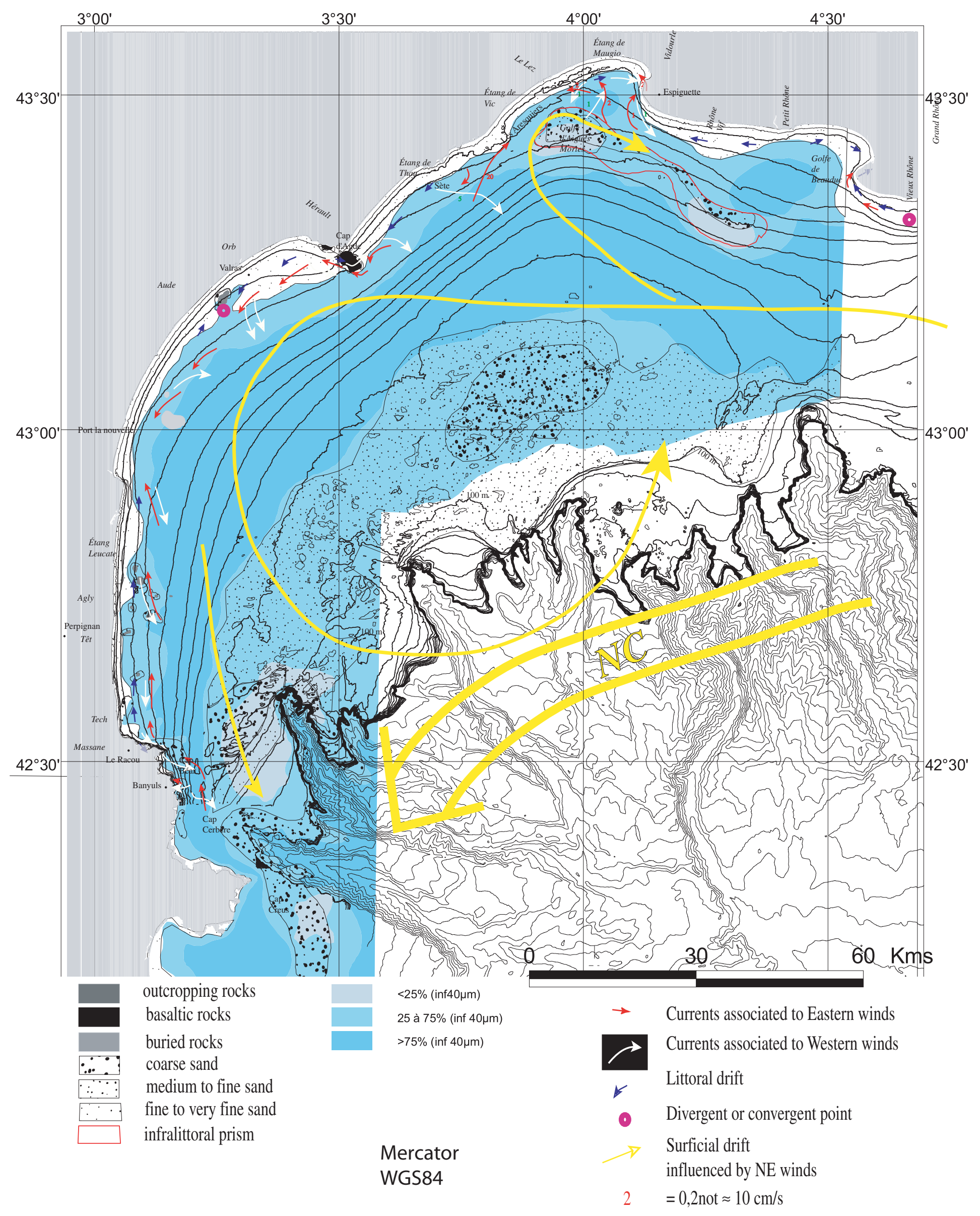


A)

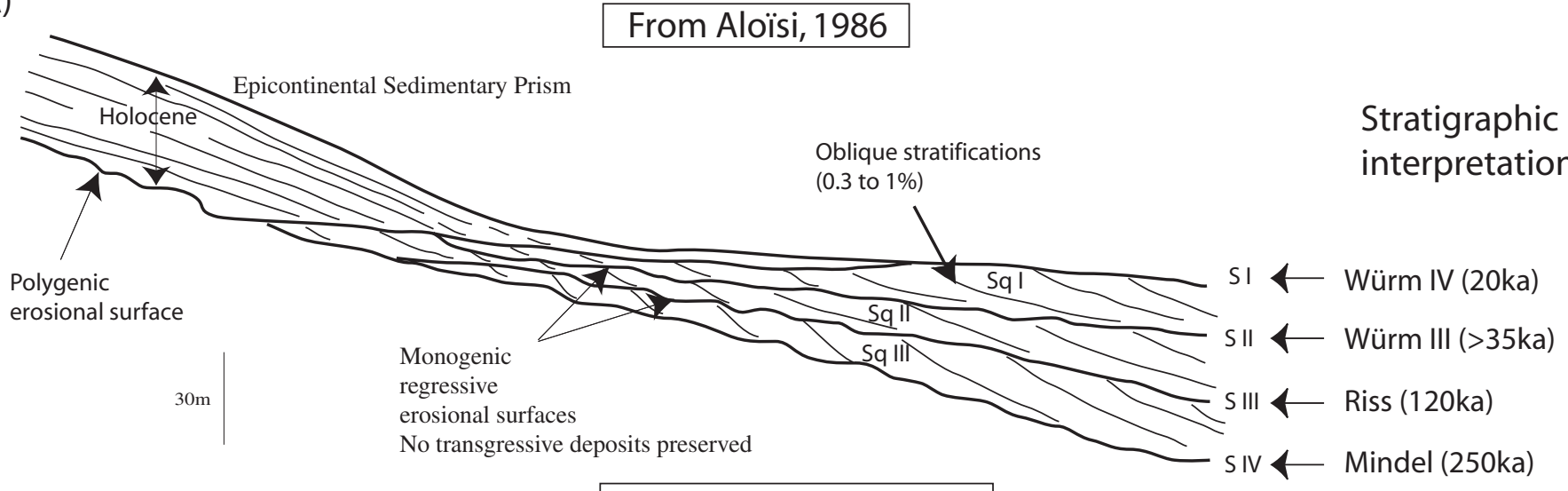

B) $\quad$ From Tesson et al., 1993

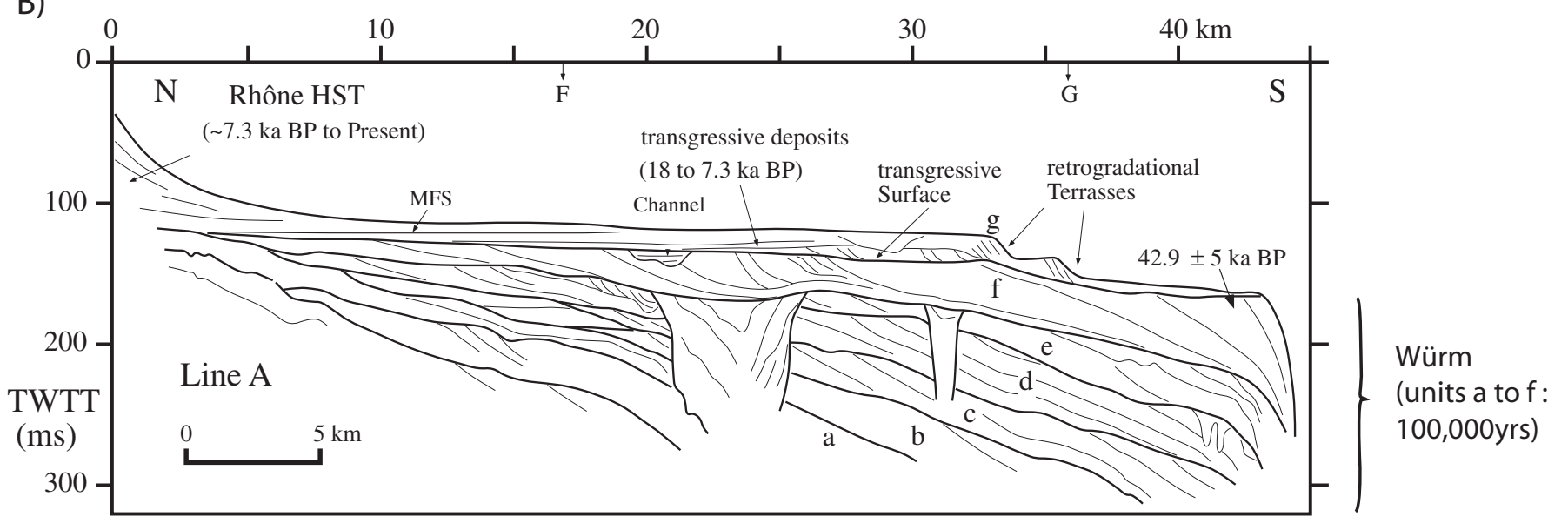

From Tesson et al., 1998

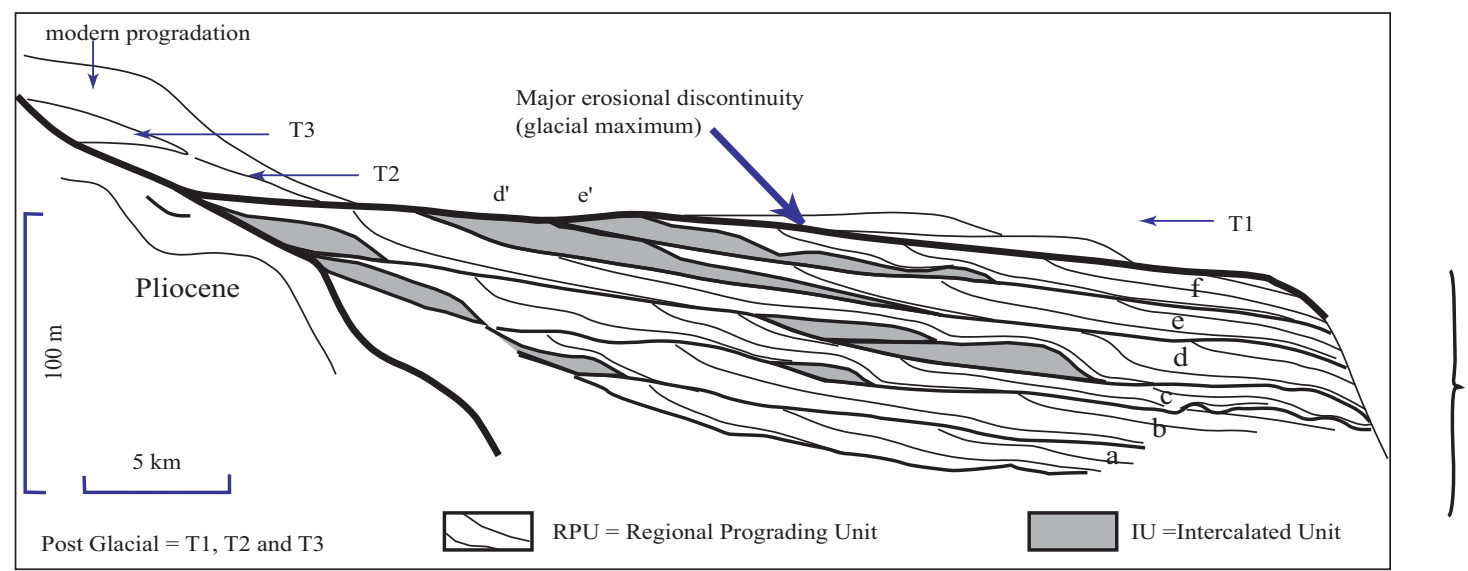

Würm

(units a to $f$ : 100,000yrs)

C)

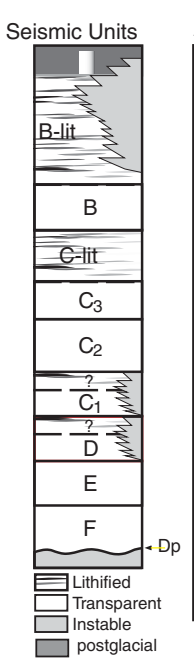

\section{Torres, 1995}

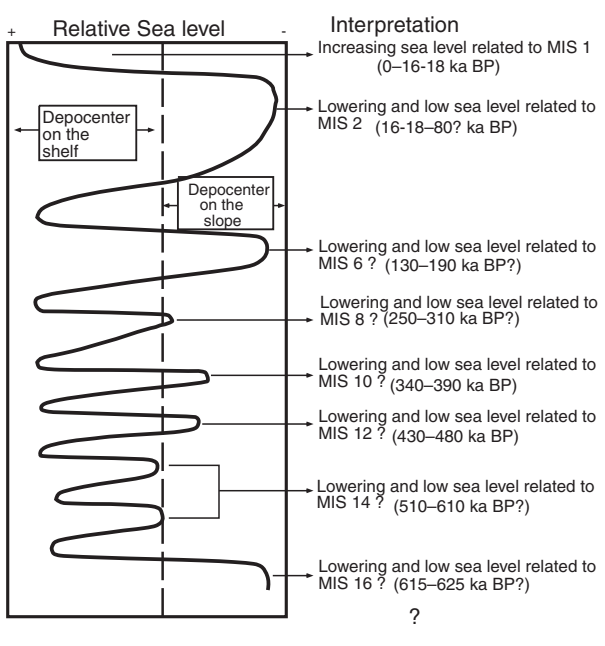

D) Tesson et al., 2000

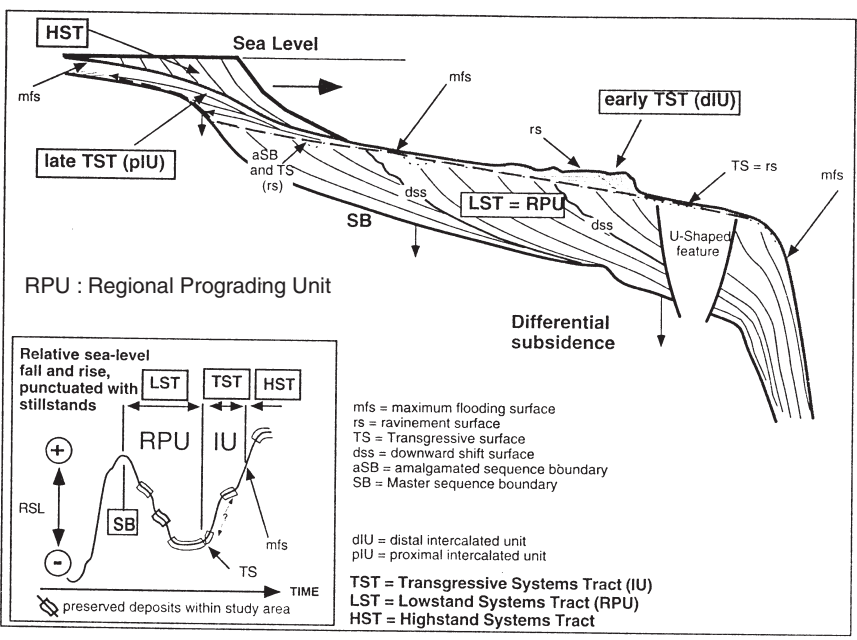




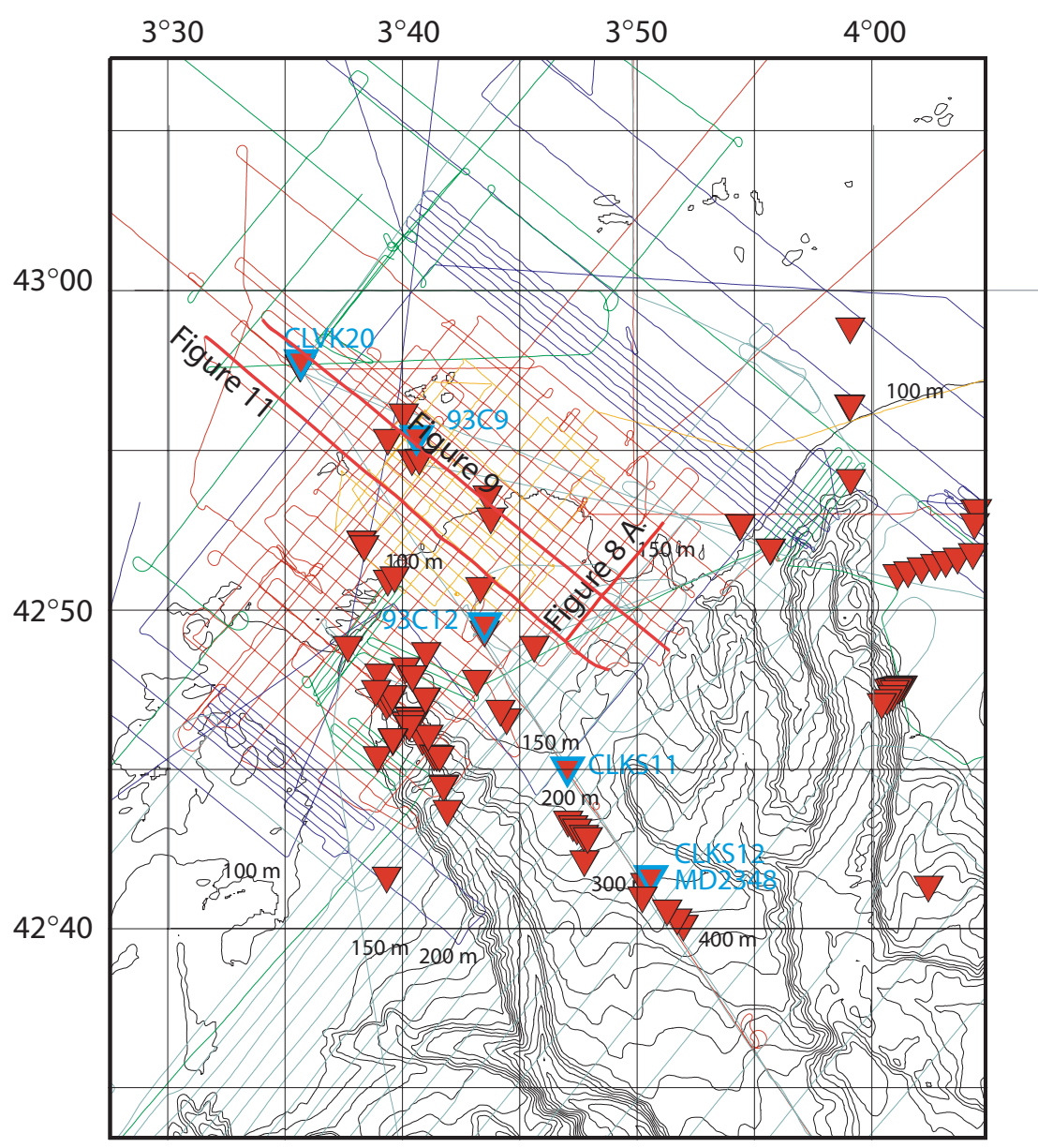

Rabineau et al., Figure 4 

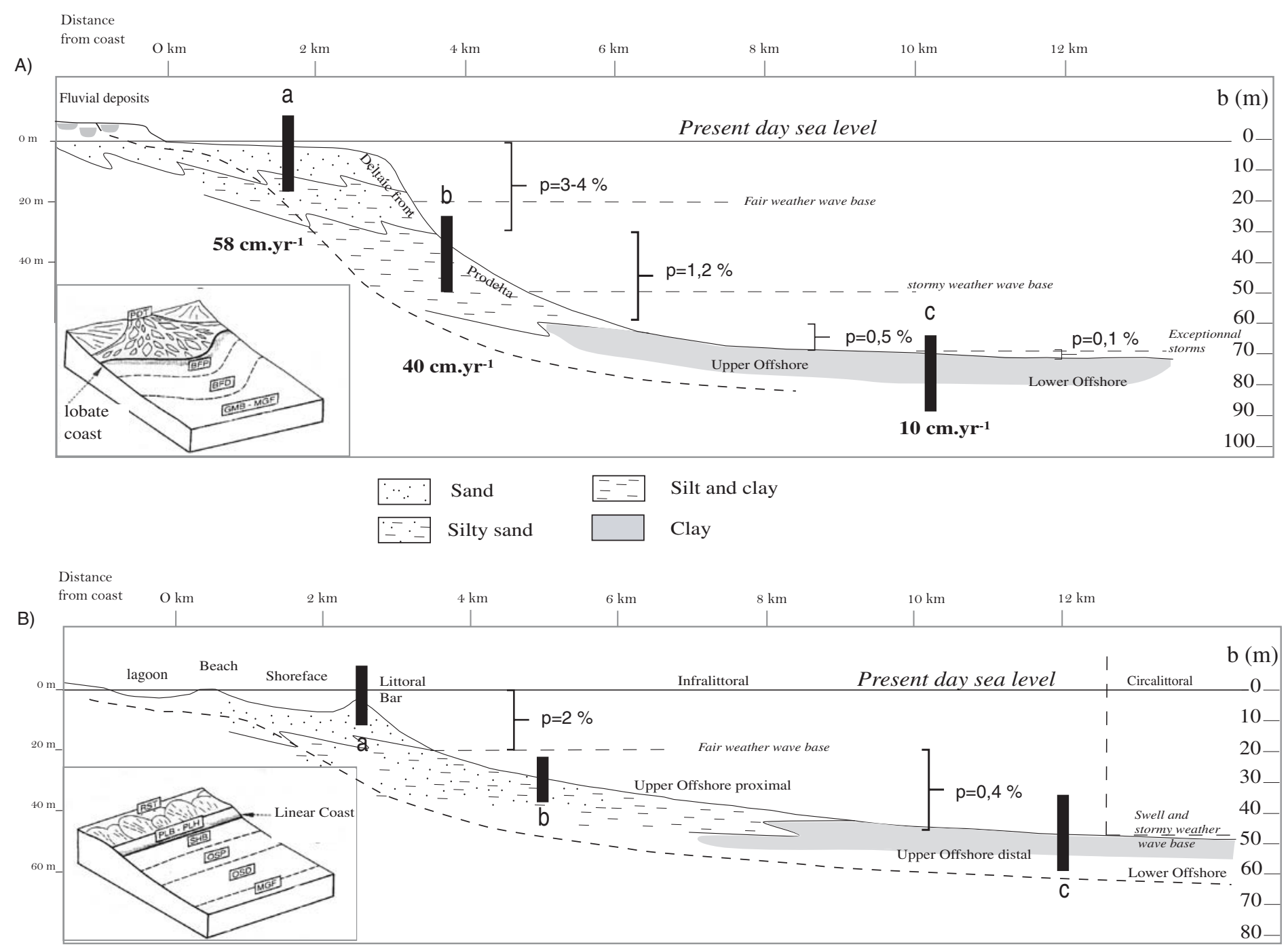

Rabineau et al., Figure 5 

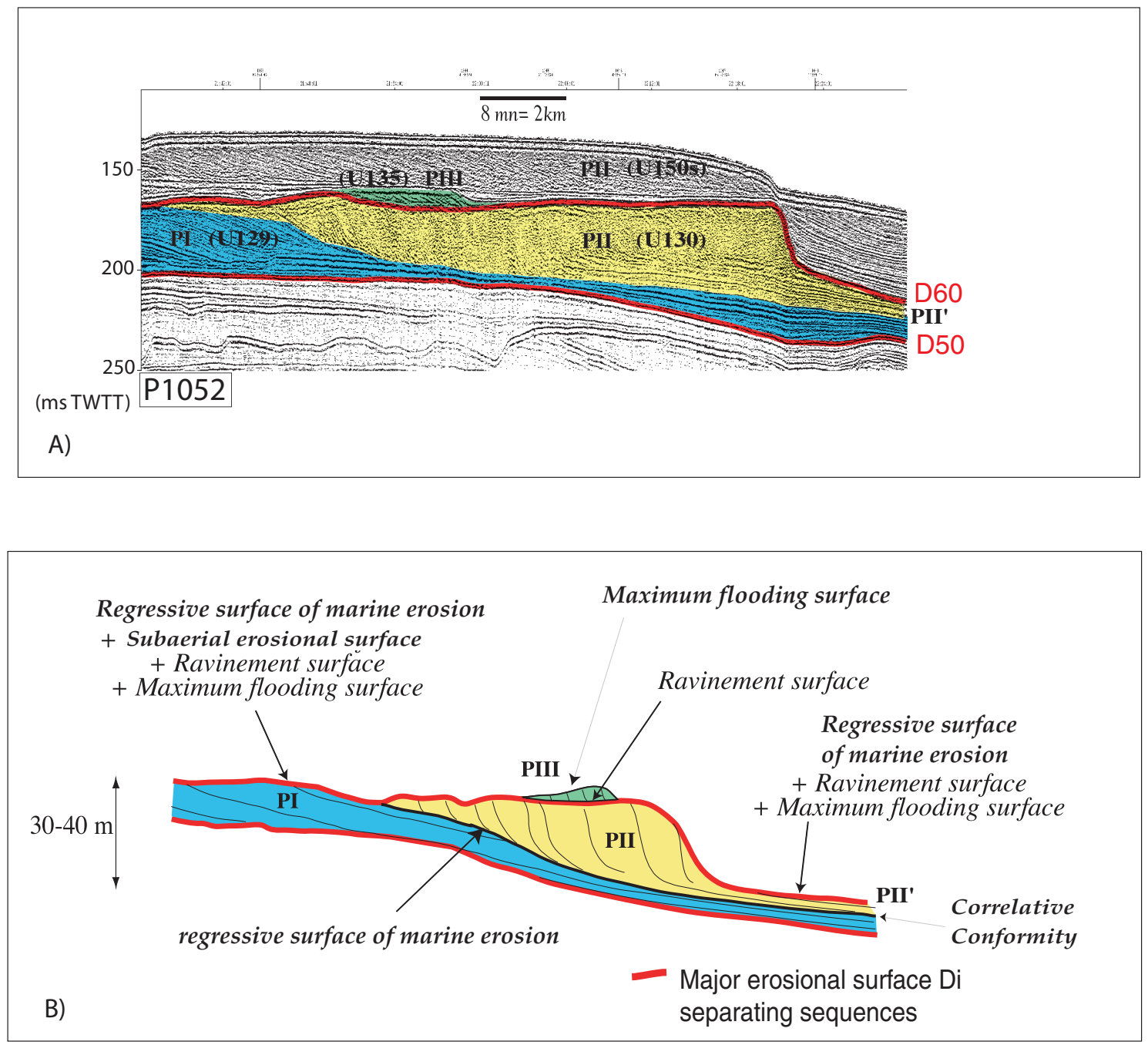

Rabineau et al., Figure 6 

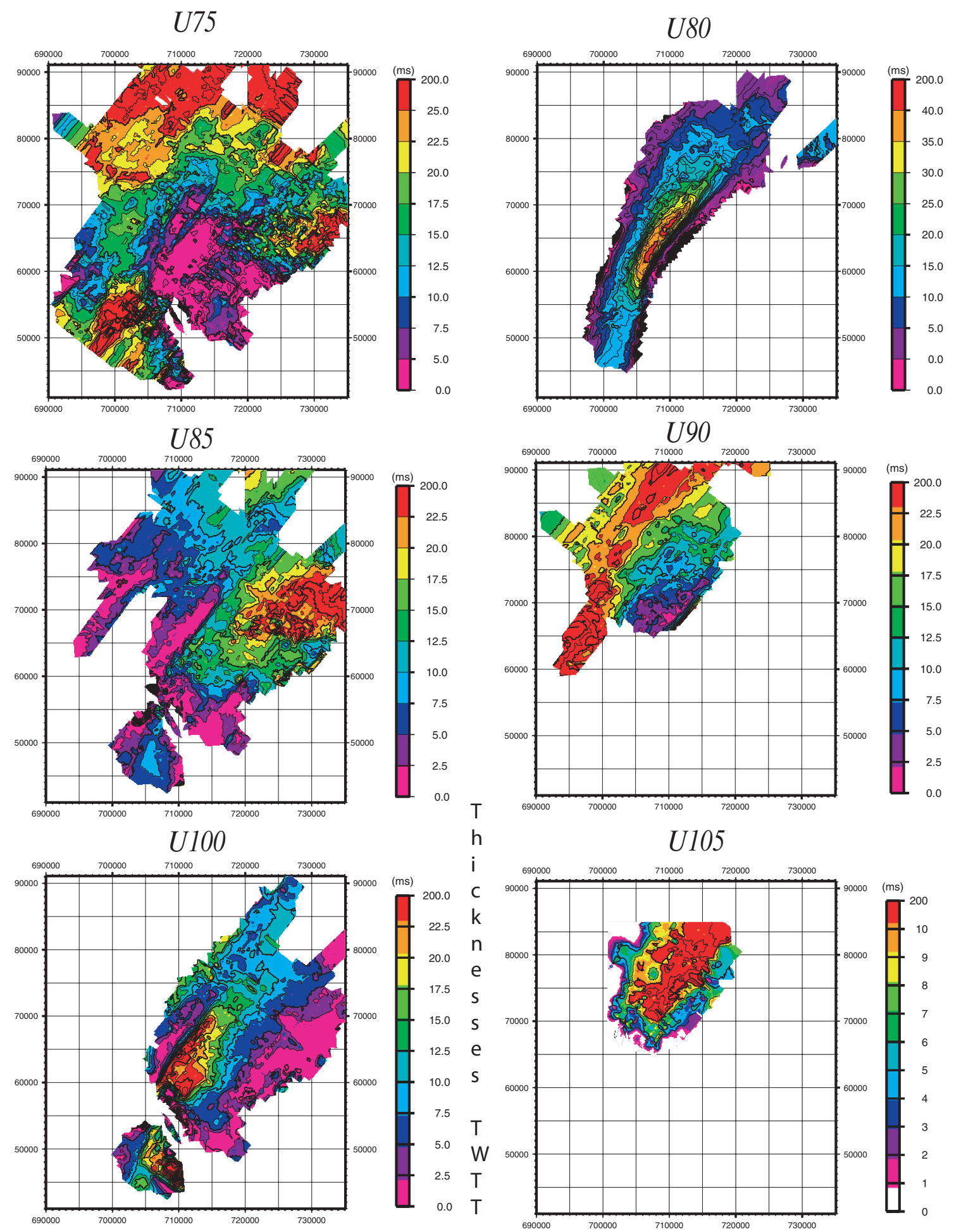

U110

(ms)

U150
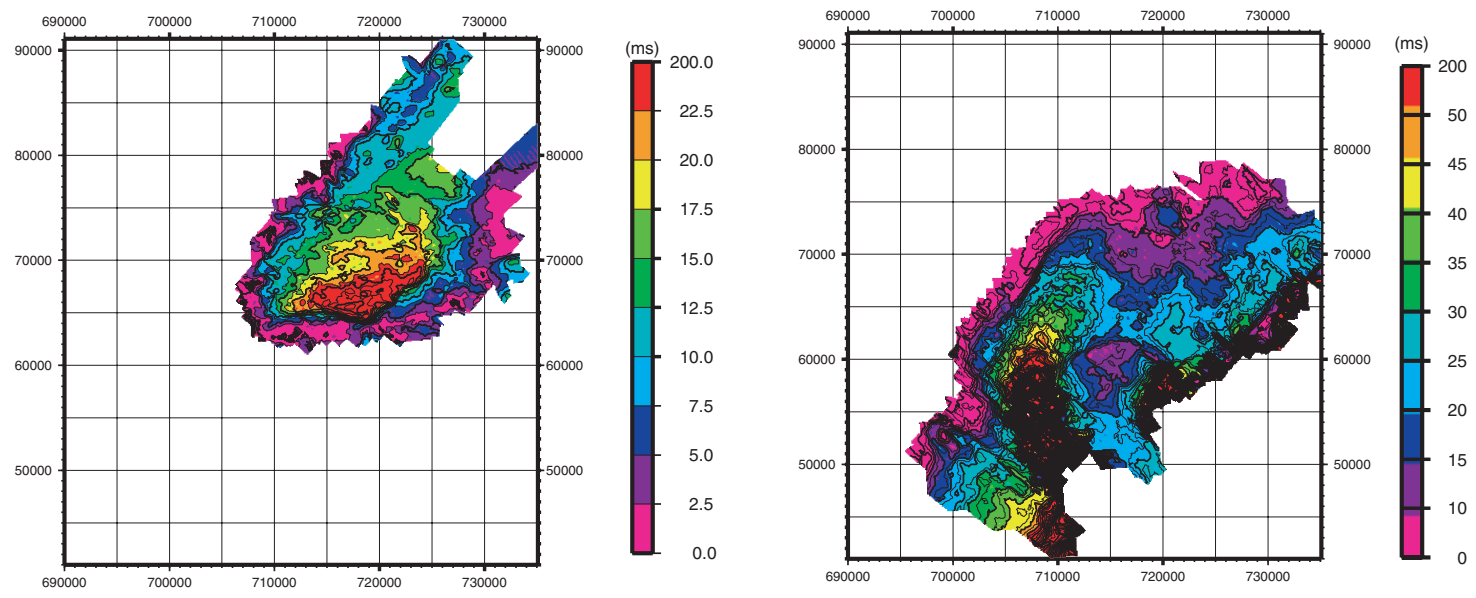


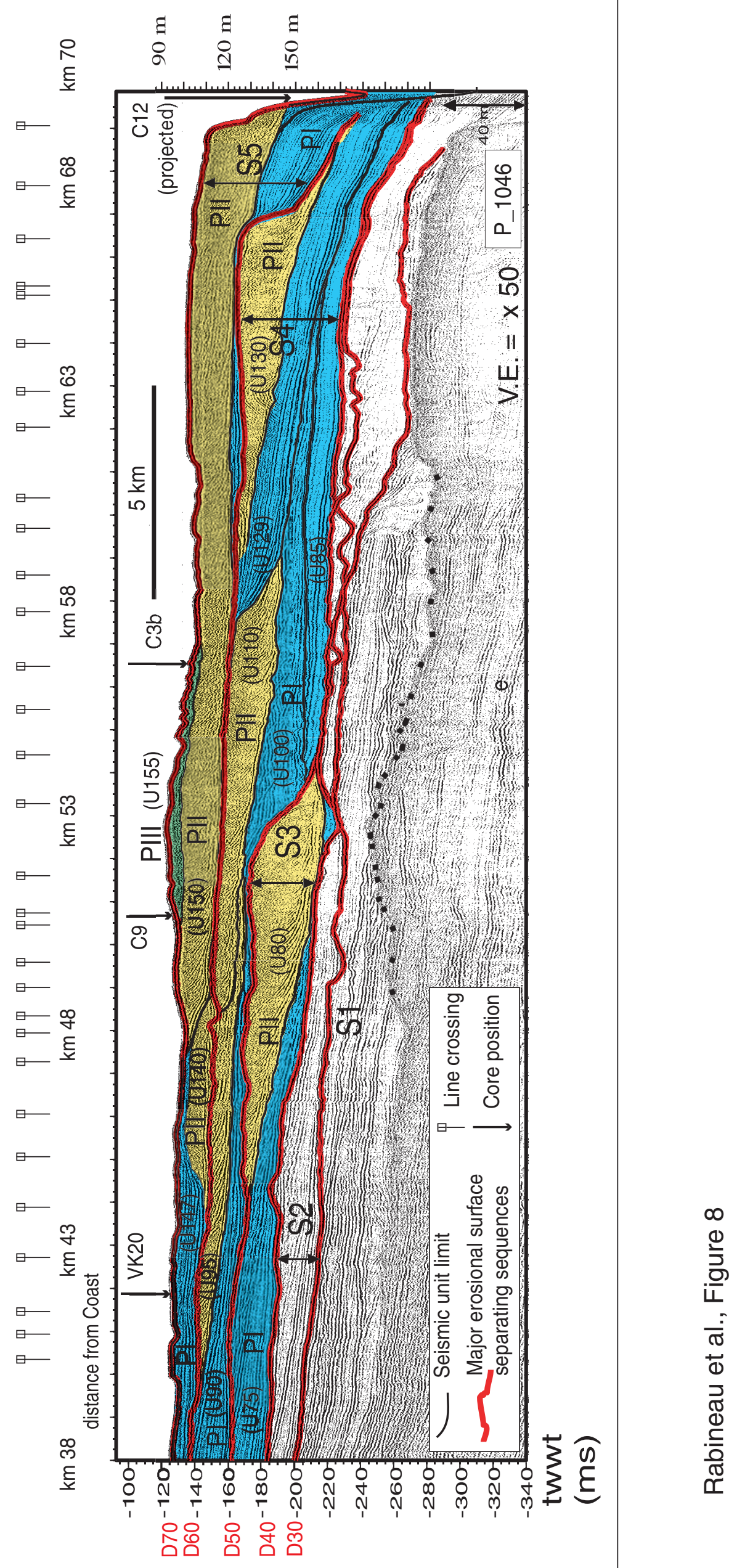




\section{D70-Top S5}
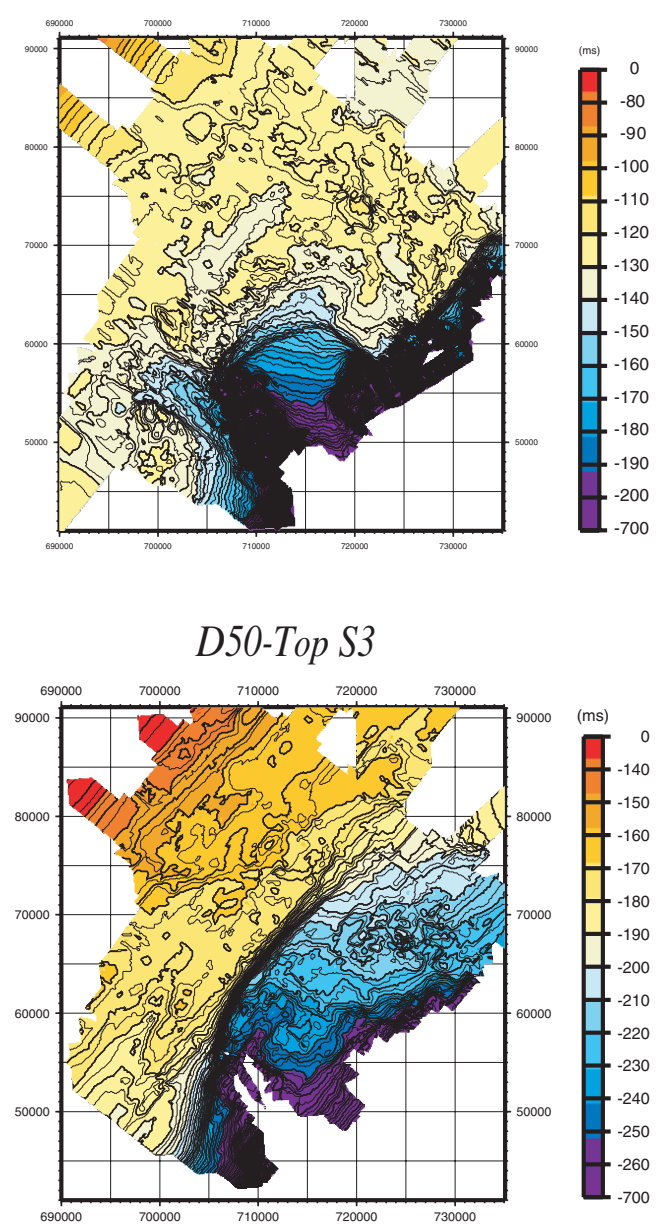

\section{D30-Top S1}

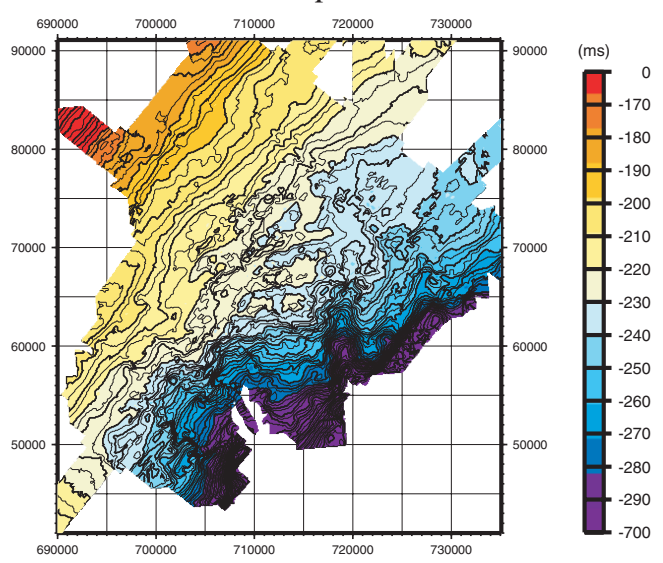

D60-Top S4

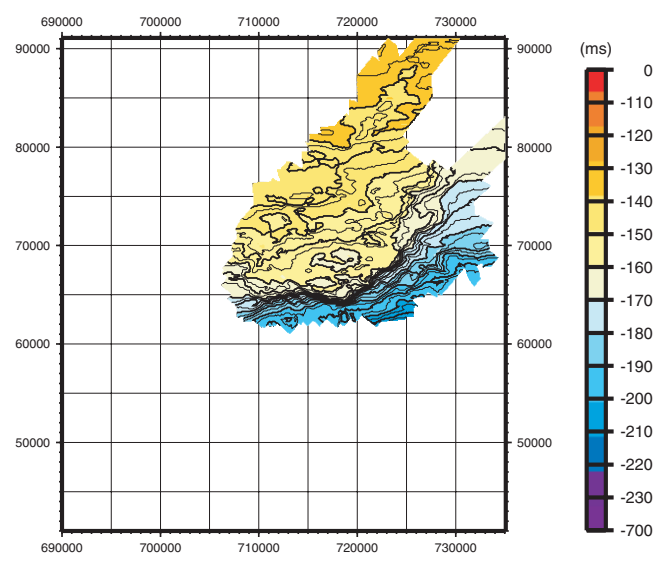

D40-Top S2

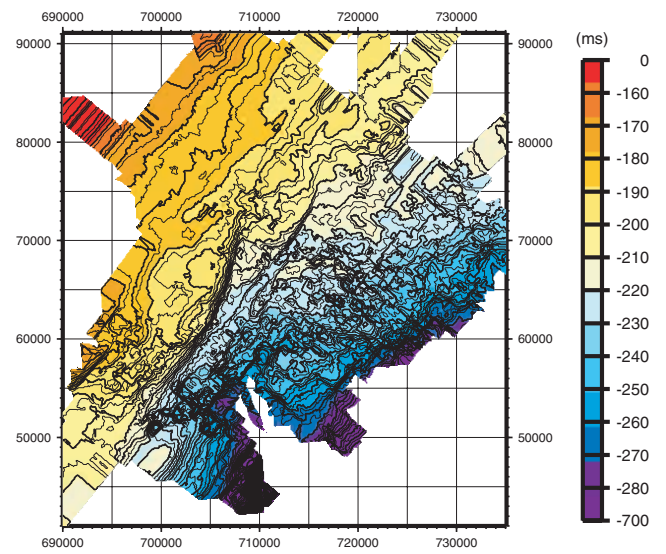




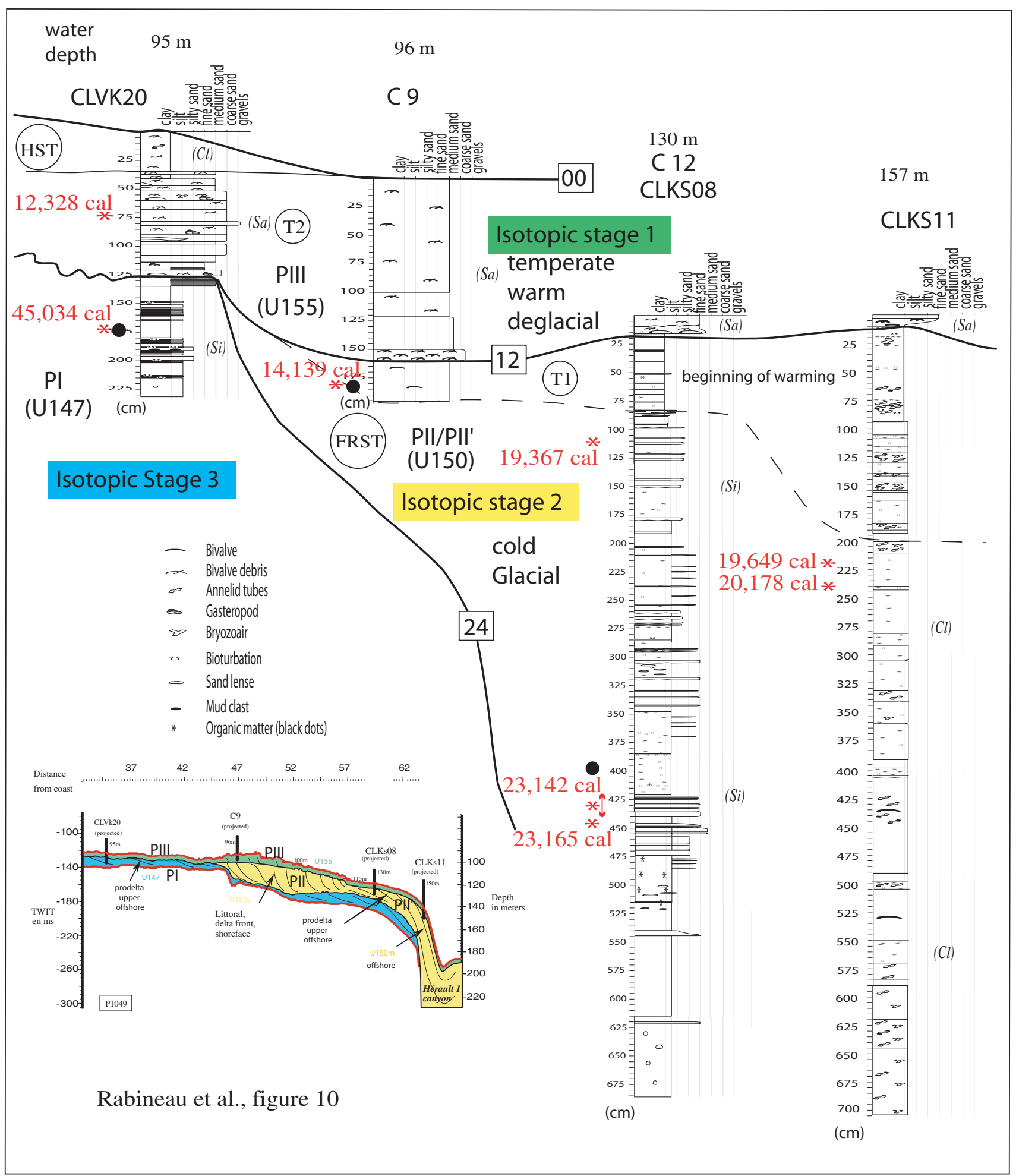




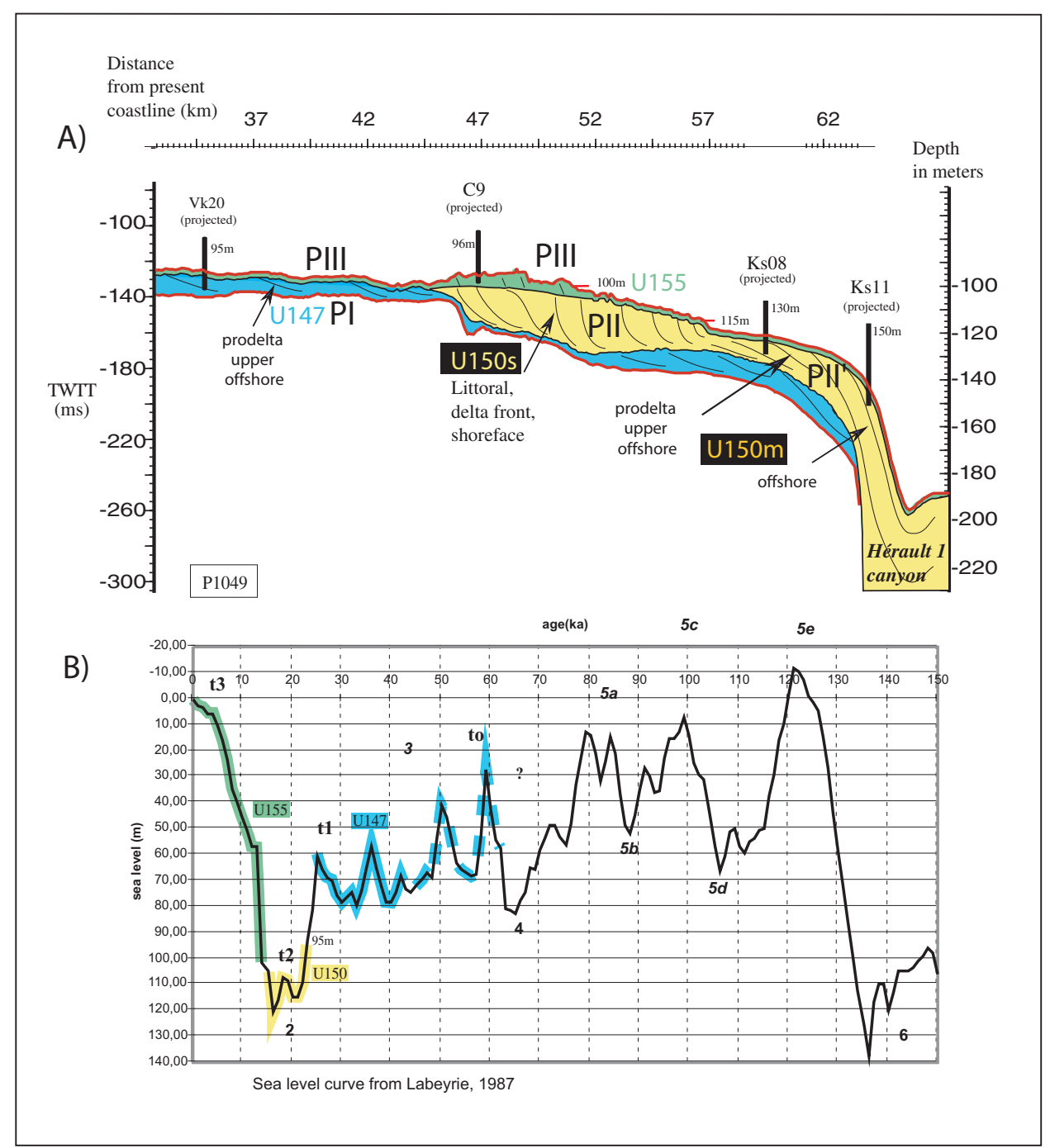

Rabineau et al., figure 11 
Distance from present

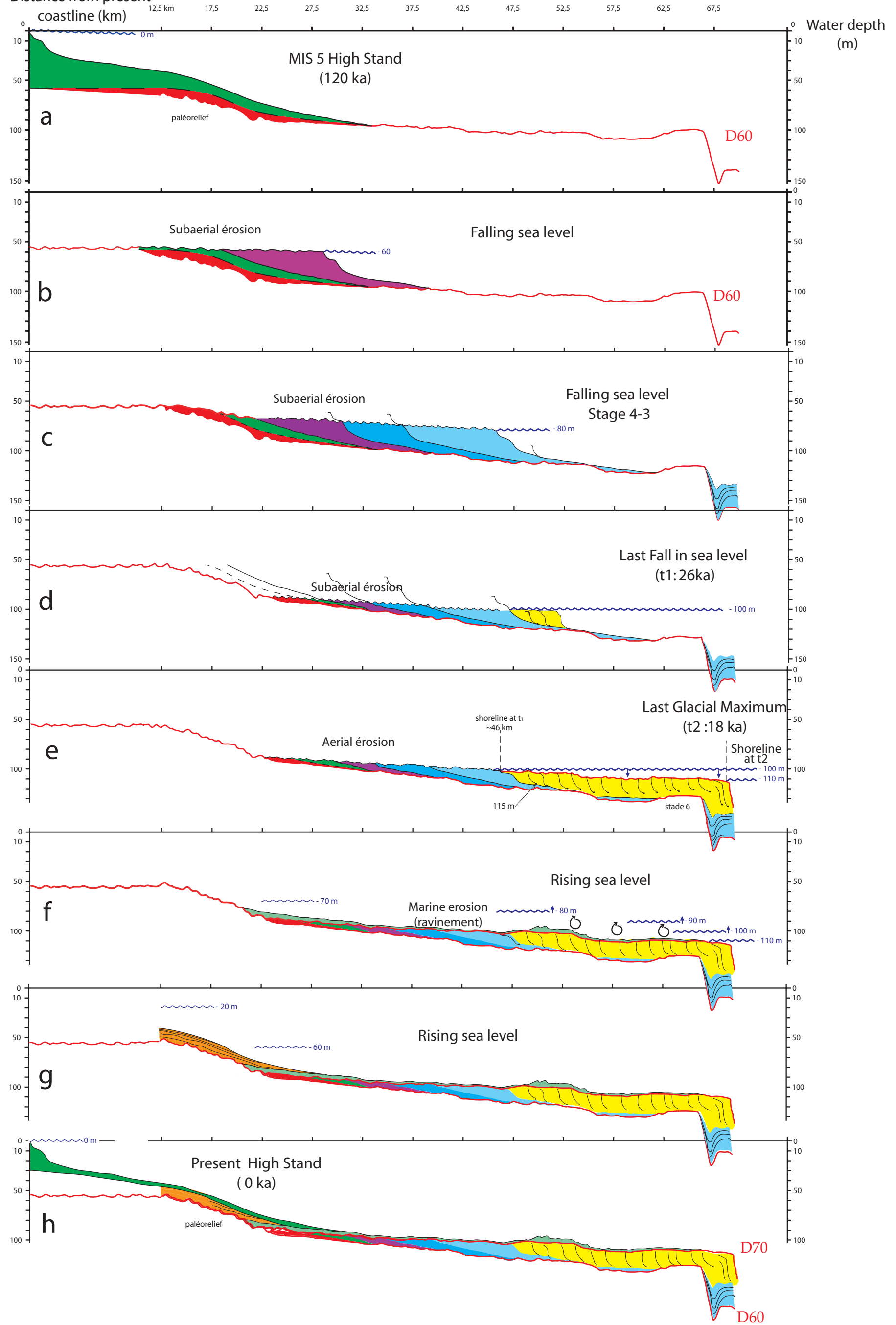

Rabineau et al., Figure 12 


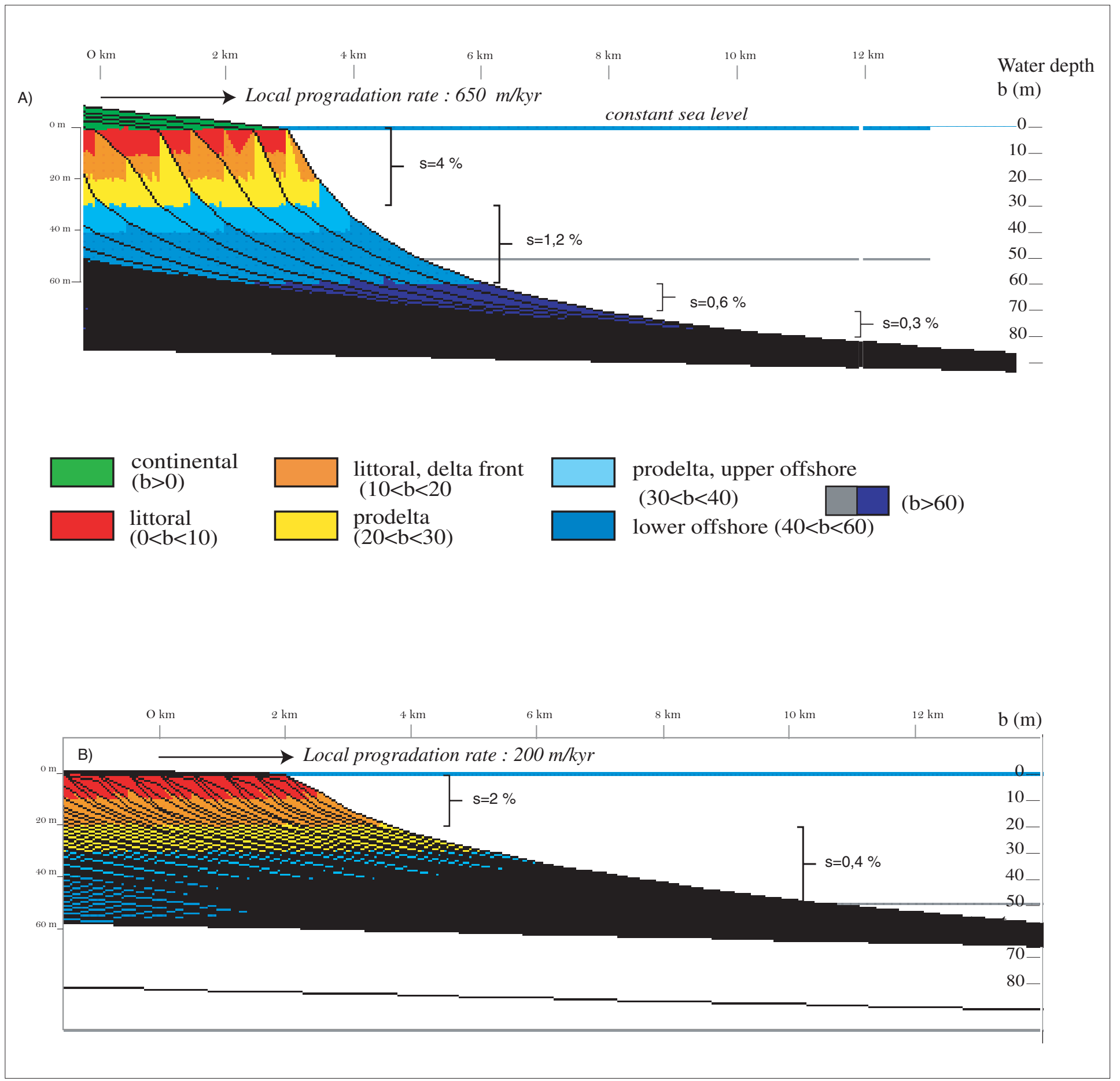

Rabineau et al., Figure 13 


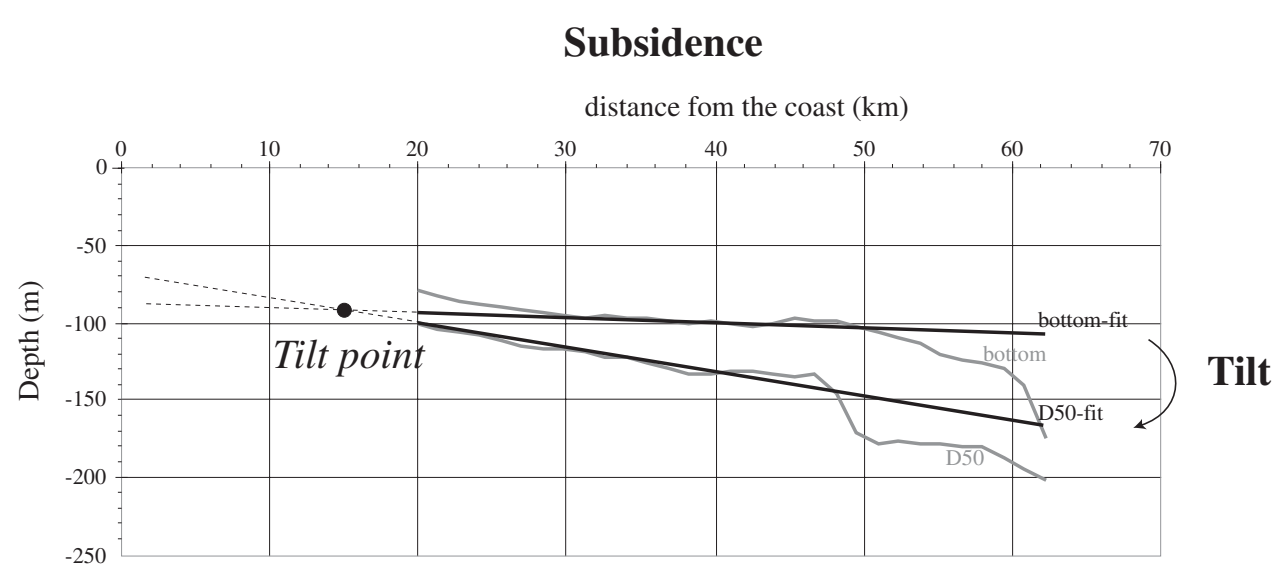

\section{Initial morphology}

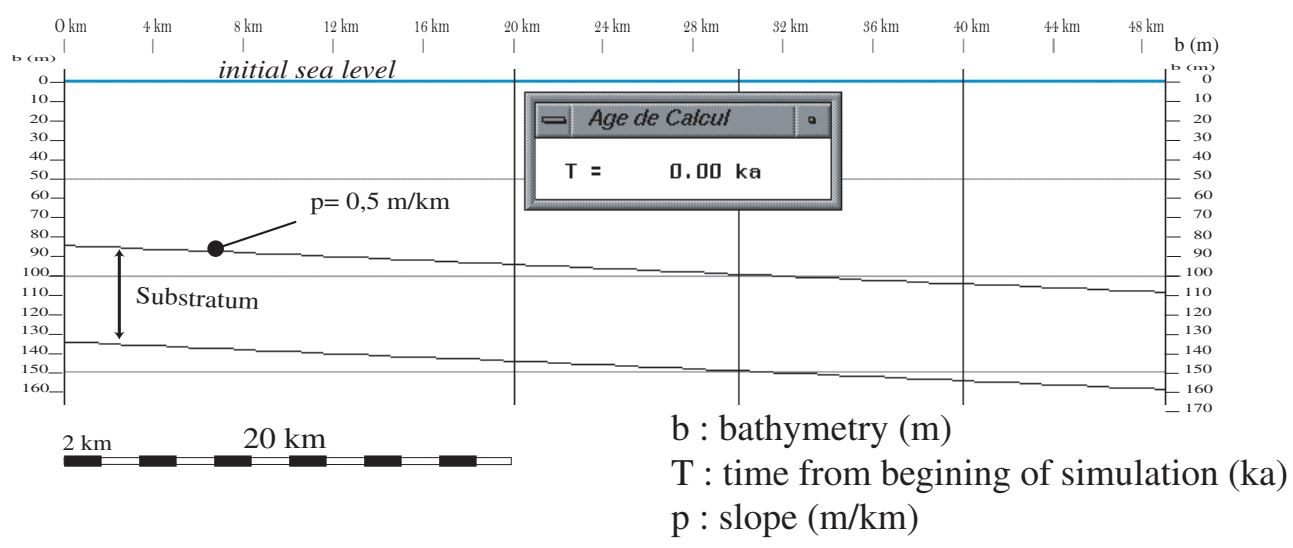

Sediment flux

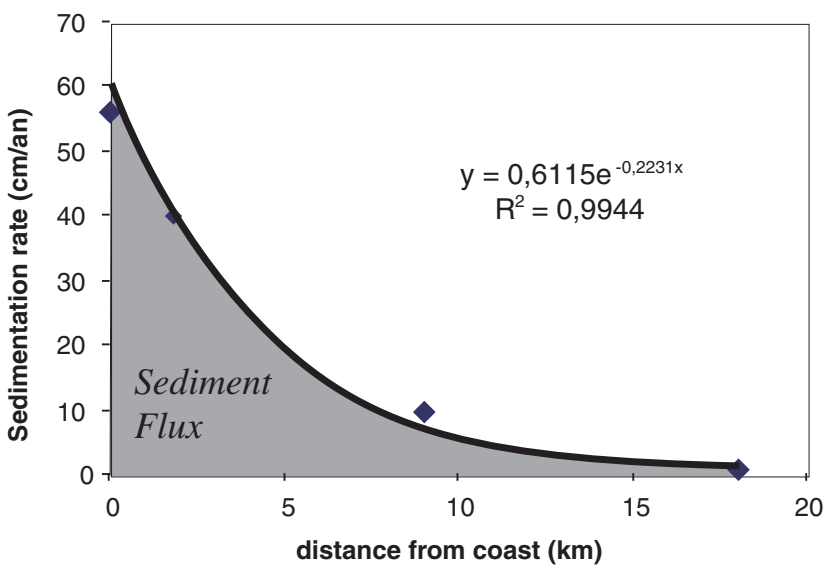

Rabineau et al., Figure 14 


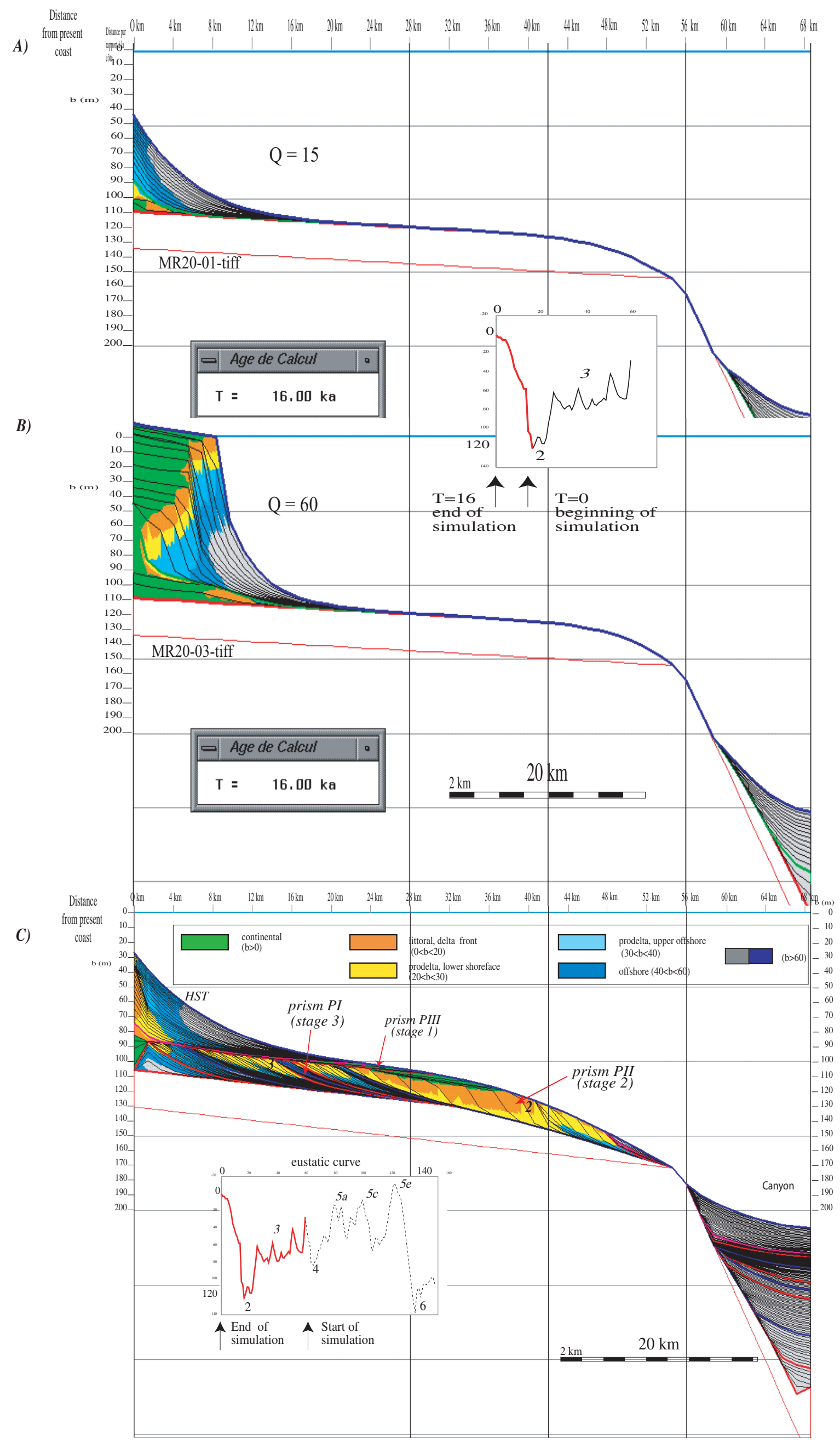




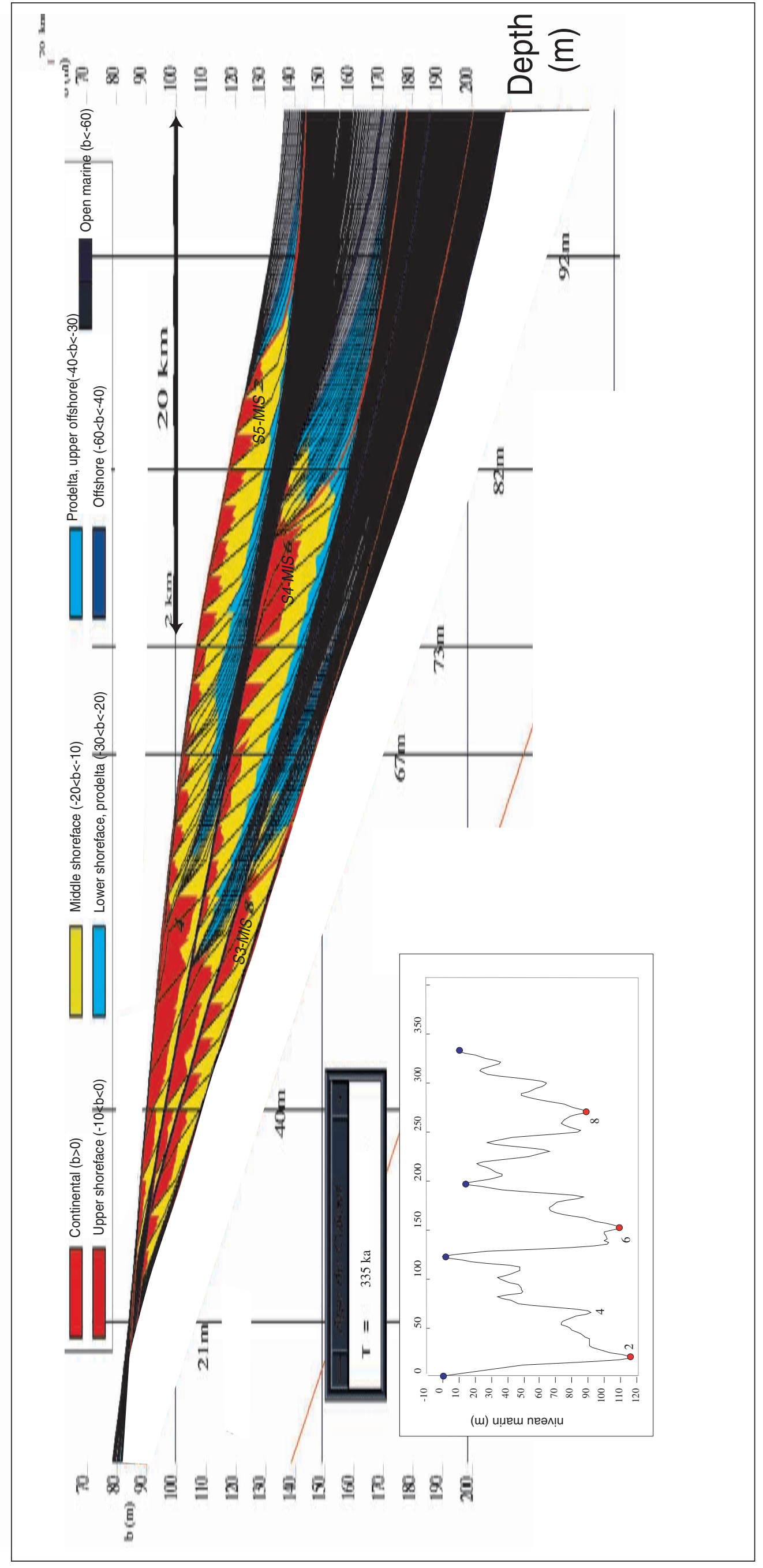

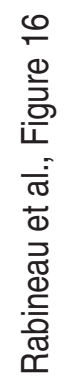



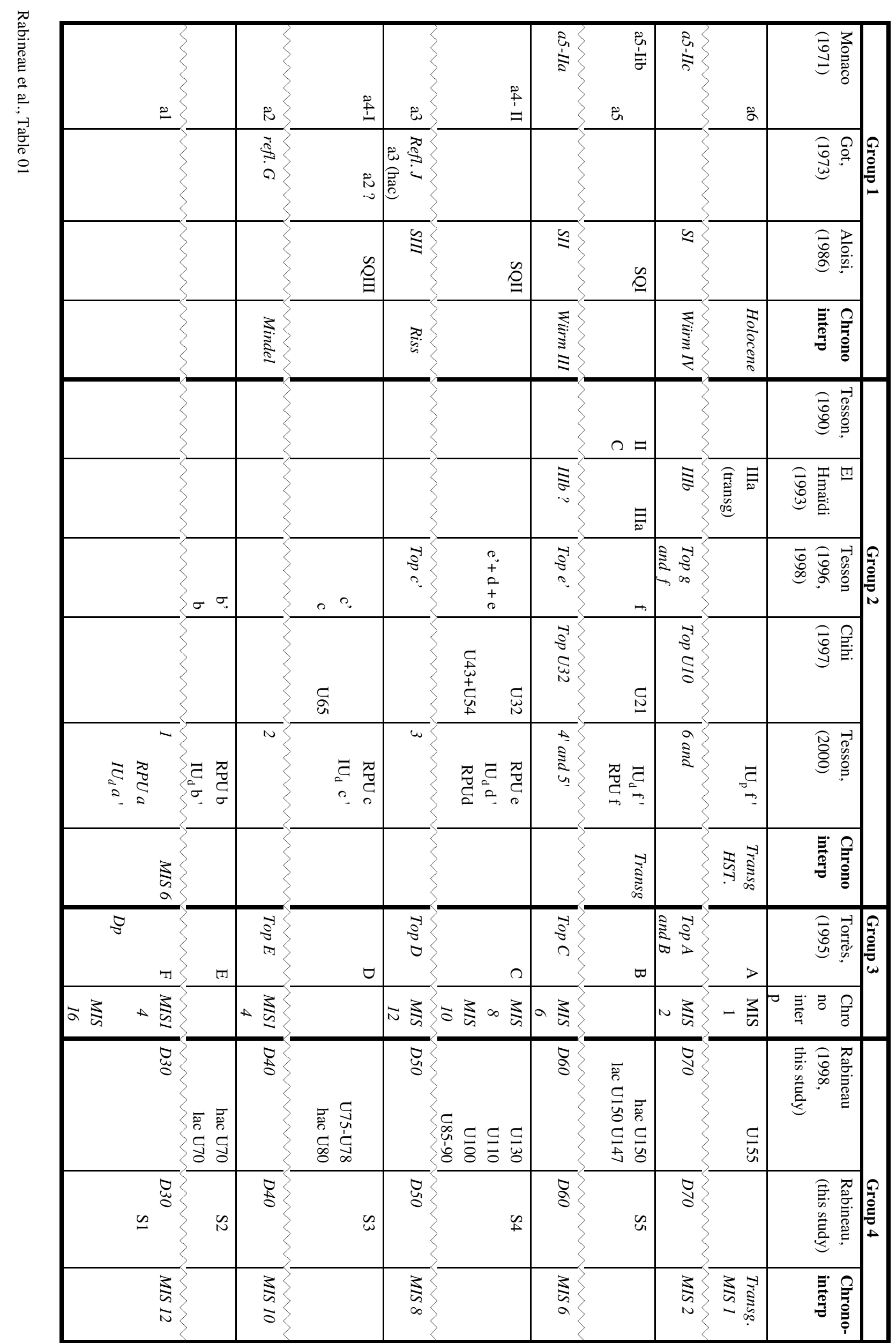


\section{Ifremer Cores}

\begin{tabular}{|c|c|c|c|c|c|c|c|c|c|}
\hline Na me & $\begin{array}{c}\text { Length } \\
(\mathbf{c m})\end{array}$ & Unit & Latitude & Longitude & $\begin{array}{c}\text { Bathy } \\
(\mathbf{m})\end{array}$ & Profil & $\begin{array}{c}\text { Time on } \\
\text { profile }\end{array}$ & Profil & $\begin{array}{c}\text { Time on } \\
\text { profile }\end{array}$ \\
\hline 93C3b & 229 & $150 \mathrm{~s}(2)-155$ & $\mathrm{~N} 4253,500$ & $\mathrm{E} 343,540$ & $\sim 98$ & 1046 & $02: 53$ & 0039 & $03: 24$ \\
\hline 93C4 & 240 & $150 \mathrm{~s}(2)-155$ & $\mathrm{~N} 4252,800$ & $\mathrm{E} 343,685$ & $\sim 103$ & 1047 & $06: 26: 30$ & 1022 & $04: 20$ \\
\hline 93C7 & 195 & $150 \mathrm{~s}(1)$ & $\mathrm{N} 4255,260$ & $\mathrm{E} 339,300$ & $\sim 99$ & 1047 & $07: 24$ & 1012 & $05: 39$ \\
\hline 93C9b & 196 & $150 \mathrm{~s}(1)$ & $\mathrm{N} 4255,320$ & $\mathrm{E} 340,525$ & $\sim 96$ & 1046 & $02: 15$ & 1042 & $14: 31: 30$ \\
\hline 94klu142 & 337 & $150 \mathrm{~m}$ & $\mathrm{~N} 4248,798$ & $\mathrm{E} 345,550$ & 126 & 1051 & $19: 33$ & -3039 & $06: 17$ \\
\hline 94klu151 & 188 & $150 \mathrm{~s}(2)$ & $\mathrm{N} 4250,641$ & $\mathrm{E} 343,228$ & 111 & 0032 & $22: 25$ & 1021 & $01: 19$ \\
\hline 94klu141b & 422 & $150 \mathrm{~m}$ & $\mathrm{~N} 4248,605$ & $\mathrm{E} 340,925$ & 132 & 1004 & $10: 07$ & 1021 & $00: 42$ \\
\hline
\end{tabular}

\section{Perpignan Cores}

\begin{tabular}{|c|c|c|c|c|c|c|c|c|c|}
\hline Name & $\begin{array}{c}\begin{array}{c}\text { Length } \\
(\mathrm{cm})\end{array} \\
\end{array}$ & Unit & Latitude & Longitude & $\begin{array}{c}\text { Bathy } \\
\text { (m) }\end{array}$ & Profil & $\begin{array}{c}\text { Time on } \\
\text { profile }\end{array}$ & Profil & $\begin{array}{c}\text { Time on } \\
\text { profile }\end{array}$ \\
\hline 93C12* & 455 & $150 \mathrm{~m}$ & $\mathrm{~N} 4249,486$ & E3 43,429 & $\sim 126$ & 1017 & $15: 04: 00$ & 1035 & $06: 24: 00$ \\
\hline 92K19 & 295 & 147 & N43 12 & E3 50 & $\begin{array}{l}\sim 92 \\
\end{array}$ & 1103 & $10: 39$ & I & 7 \\
\hline
\end{tabular}

\section{Ifremer Calmar Cores}

\begin{tabular}{|c|c|c|c|c|c|c|c|c|c|}
\hline Name & $\begin{array}{c}\text { Length } \\
\text { (cm) }\end{array}$ & Unit & Latitude & Longitude & $\begin{array}{c}\text { Bathy } \\
\text { (m) }\end{array}$ & Profil & $\begin{array}{c}\text { Time on } \\
\text { profile }\end{array}$ & Profil & $\begin{array}{c}\text { Time on } \\
\text { profile }\end{array}$ \\
\hline 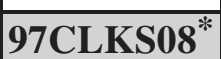 & 686 & $150 \mathrm{~m}$ & N42 49,494 & E3 43,379 & 130 & 1017 & $15: 04$ & 1035 & $06: 24$ \\
\hline 97CLKS09\# & 250 & $150 \mathrm{~s}-\mathrm{m}$ & N42 51,826 & E3 55,618 & 124 & 1059 & $05: 42: 30$ & 1058 & $05: 29: 20$ \\
\hline \begin{tabular}{|l|} 
97CLKS11 \\
\end{tabular} & 704 & $150 \mathrm{~m}$ & N42 44,990 & E3 46,960 & 157 & 1036 & $08: 13: 40$ & I & $T$ \\
\hline 97CLKS12 & 636 & $150 \mathrm{~m}$ & N42 41,390 & E3 50,260 & 301 & 1036 & $09: 15: 50$ & 7 & T \\
\hline 97CLKS18 & 180 & 147 & N42 57,564 & E3 35,572 & 95 & 1047 & 08:13:00 & 1060 & $09: 11: 30$ \\
\hline 97CLKS21 & 100 & 147 & N43 12,008 & E3 49,824 & 94 & 1103 & $10: 39$ & 7 & 7 \\
\hline 97CLVK13 \# & 80 & & N42 51,832 & E3 55,591 & 123 & 1059 & $05: 42: 30$ & 1058 & $05: 29: 20$ \\
\hline 97CLVK14 & 40 & 155 & N42 52,601 & E3 54,305 & 97 & 1059 & $06: 00: 20$ & 7 & $T$ \\
\hline 97CLVK15 & 50 & 155 & N42 52,600 & E3 54,309 & 97 & 1059 & 06:00:20 & I & $T$ \\
\hline 97CLVK16 & 43 & $150 \mathrm{~s}-\mathrm{m}$ & N42 54,628 & E3 40,344 & 96 & 1047 & $07: 09: 30$ & 1003 & $08: 07: 00$ \\
\hline \begin{tabular}{|l|} 
97CLVK17 \\
\end{tabular} & 75 & $155-140$ & N42 56,044 & E3 39,977 & 100 & 1045 & $23: 26: 20$ & 1012 & $05: 28: 20$ \\
\hline 97CLVK20 ${ }^{\beta}$ & 235 & 147 & N42 57,552 & E3 35,565 & 95 & 1047 & $08: 13: 00$ & $\begin{array}{l}1060 \\
4026\end{array}$ & $09: 11: 30$ \\
\hline
\end{tabular}

Rabineau et al., Table 2 


\begin{tabular}{|c|c|c|c|}
\hline$\approx$ & $\Omega$ & $\cong$ & 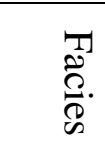 \\
\hline 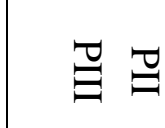 & $\exists$ & $\Xi$ & 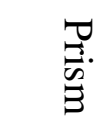 \\
\hline 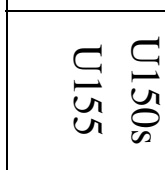 & $\stackrel{\subseteq}{ज}$ & 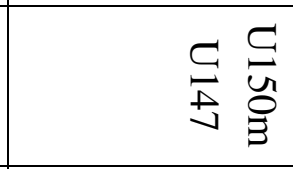 & $\stackrel{\Xi}{\Xi}$ \\
\hline ใ & 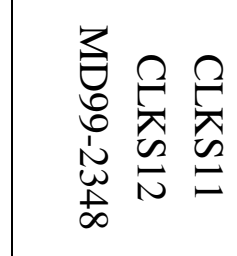 & 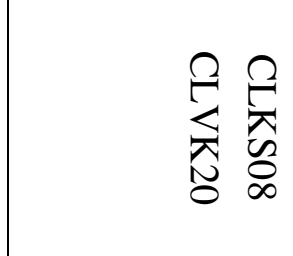 & 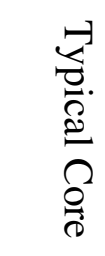 \\
\hline 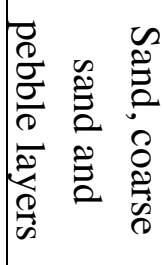 & 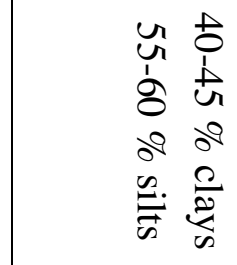 & 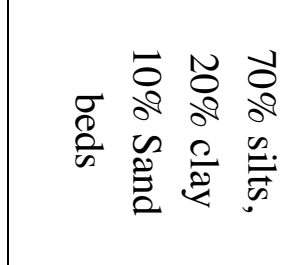 & 咅 \\
\hline $\begin{array}{ll}3 & 0 \\
0 & 0 \\
0 & 0 \\
0 & 0\end{array}$ & 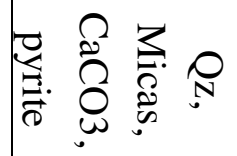 & 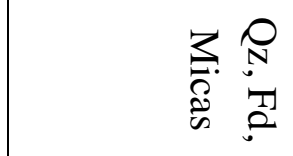 & 客. \\
\hline 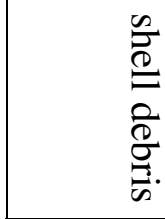 & 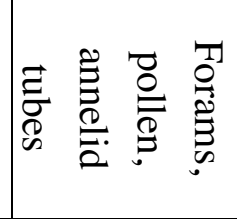 & 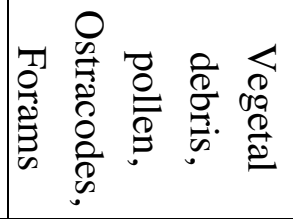 & 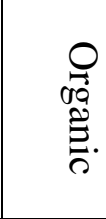 \\
\hline 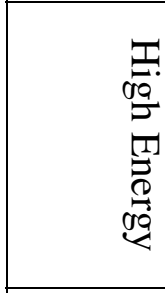 & 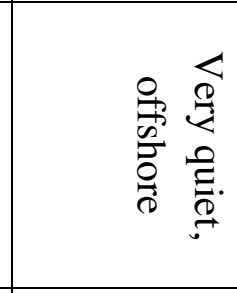 & 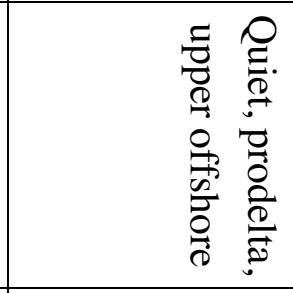 & $\begin{array}{l}\text { T. } \\
3 \\
3 \\
0 \\
0 \\
0 \\
0 \\
0 \\
0 \\
0\end{array}$ \\
\hline 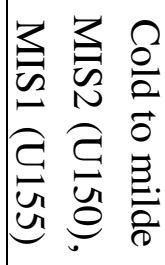 & 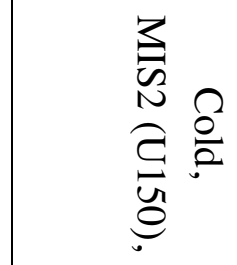 & 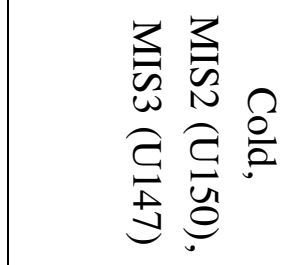 & $\begin{array}{l}\stackrel{2}{\Xi} \\
\stackrel{0}{*}\end{array}$ \\
\hline $\begin{array}{l}\text { i } \\
\text { Oे } \\
\Xi\end{array}$ & $\begin{array}{l}\text { t } \\
\dot{1} \\
\text { oे } \\
\vdots\end{array}$ & $\begin{array}{l}\text { W } \\
\vdots \\
\vdots \\
\vdots\end{array}$ & 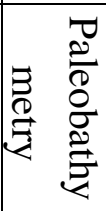 \\
\hline
\end{tabular}




\begin{tabular}{|c|c|c|c|c|c|c|}
\hline \multirow[t]{2}{*}{ Core } & \multirow[t]{2}{*}{ Position } & \multirow{2}{*}{$\begin{array}{c}\text { Present } \\
\text { water } \\
\text { depth } \\
(\mathrm{m})\end{array}$} & \multirow{2}{*}{$\begin{array}{l}\text { Depth } \\
\text { in core } \\
(\mathrm{cm})\end{array}$} & \multirow{2}{*}{$\begin{array}{l}\text { Material } \\
\text { used }\end{array}$} & \multirow[t]{2}{*}{$\begin{array}{l}\text { C14 Datation } \\
\text { (year BP) }\end{array}$} & $\begin{array}{l}\text { Calendar datation } \\
\text { (year BP) } \\
\text { Calib4.1 (50) }\end{array}$ \\
\hline & & & & & & ${ }^{\star}$ Glacial Polynomial \\
\hline C12 & $\begin{array}{l}\mathrm{N} 42^{\circ} 49^{\prime} \\
\mathrm{E}^{\circ} 43^{\prime}\end{array}$ & 130 & $\begin{array}{l}105-115 \\
245-255 \\
420-440 \\
440-450 \\
\end{array}$ & $\begin{array}{c}\text { Forams } \\
\text { Organic Matter } \\
\text { Lamellibranchiat: } \\
\text { Lamellibranchiat }\end{array}$ & \begin{tabular}{|c}
$16,740+/-240($ OXA $)$ \\
$29715+/-975($ OXA $)$ \\
$20,020+/-210$ \\
$20,040+/-400$ \\
\end{tabular} & $\begin{array}{l}\text { 19, } 367 \text { BP }(18.9-19.7 \\
23,142 \text { BP }(22.7-23.6 \\
23,165 \text { BP }(22.5-23.8\end{array}$ \\
\hline K19 & $\begin{array}{l}\mathrm{N} 43^{\circ} 12^{\prime} \\
\mathrm{E} 3^{\circ} 50^{\prime}\end{array}$ & 92 & $\begin{array}{c}80-85 \\
125-130 \\
160-170 \\
230-240 \\
285-290 \\
\end{array}$ & $\begin{array}{l}\text { Lamellibranchiat } \\
\text { Shell } \\
\text { Microfauna } \\
\text { Lamellibranchiat } \\
\text { Marine Fauna } \\
\end{array}$ & $\begin{array}{c}8,580+/-85 \\
12,180+/-80(\text { OXA) } \\
27,565+/-360 \text { (OXA) } \\
39,405+/-2250 \text { (OXA) } \\
>47500 \\
\end{array}$ & $\begin{array}{c}9,000 \mathrm{BP}(8.9-9.3) \\
13,689 \mathrm{BP}(13.4-13.8 \\
31,804 \mathrm{BP}^{*} \\
44,713 \mathrm{BP} * \\
>53,052 \mathrm{BP} *\end{array}$ \\
\hline CLKS11 & $\begin{array}{r}\mathrm{N} 42^{\circ} 45^{\prime} \\
\mathrm{E} 3^{\circ} 47^{\prime} \\
\end{array}$ & 157 & $\begin{array}{l}216-219 \\
236-239 \\
\end{array}$ & $\begin{array}{l}\text { Serpulid tests } \\
\text { Serpulid tests }\end{array}$ & $\begin{array}{l}16,985+/-110(\mathrm{OX}) \\
17,445+/-100(\mathrm{OX}) \\
\end{array}$ & $\begin{array}{r}19,649 \text { BP (19.3-20) } \\
20,178 \text { BP (19.8-20.5 }\end{array}$ \\
\hline CLVK20 & $\begin{array}{r}\mathrm{N} 42^{\circ} 57,2^{\prime} \\
\mathrm{E}^{\circ} 35,5^{\prime} \\
\end{array}$ & 95 & $\begin{array}{c}68-74 \\
171-175 \\
\end{array}$ & $\begin{array}{c}\text { Lamellibranchiat申 } \\
\text { Ostracodes }\end{array}$ & $\begin{array}{l}10,875+/-120 \\
39,710+/-720 \\
\end{array}$ & $\begin{array}{c}12,328 \mathrm{BP}(11.8-12.8 \\
45,034 \mathrm{BP}^{*} \\
\end{array}$ \\
\hline C9 & $\begin{array}{r}N 42^{\circ} 55,3^{\prime} \\
E 3^{\circ} 40,5^{\prime}\end{array}$ & 96 & $175-188$ & Lamellibranchiata & $12,710+/-80$ & 14,139 BP (14.1-15) \\
\hline
\end{tabular}

Rabineau et al., table 04 


\begin{tabular}{|c|c|c|}
\hline Modern depositional environments & Water depth $\boldsymbol{b}$ & slopes $\boldsymbol{p}$ (m/km) \\
\hline Continental & $b<0$ & $0,5<p<1$ \\
\hline beach & $0<b<5$ & $1<p<3$ \\
\hline Delta front, upper-middle shoreface & $5<b<20$ & $20<p<30$ \\
fairweather wave base & & \\
\hline prodelta, lower shoreface \\
upper offshore & $20<b<30$ & $20<p<30$ \\
storm wave base $\quad 30<b<40$ & \\
\hline lower offshore & & \\
\hline open marine & $40<b<60$ & $5<p<10$ \\
\hline
\end{tabular}

\section{Rabineau et al., Table 05}




\begin{tabular}{|c|c|c|c|c|c|c|c|}
\hline 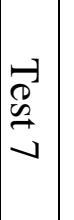 & $\begin{array}{l}\overrightarrow{0} \\
\stackrel{0}{a} \\
a\end{array}$ & 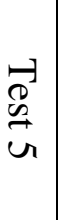 & $\begin{array}{l}\vec{A} \\
\vec{a} \\
\vec{\perp}\end{array}$ & $\begin{array}{l}\overrightarrow{0} \\
0 \\
\omega \\
\omega\end{array}$ & $\begin{array}{l}\overrightarrow{0} \\
\stackrel{\mathscr{n}}{N}\end{array}$ & $\begin{array}{l}\overrightarrow{0} \\
\stackrel{0}{\Xi} \\
\stackrel{0}{\square}\end{array}$ & 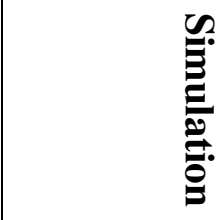 \\
\hline 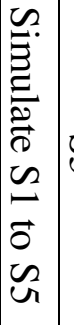 & 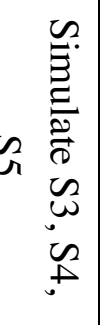 & 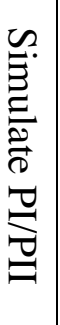 & 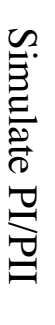 & 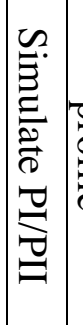 & 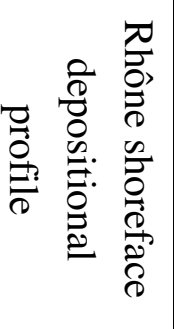 & 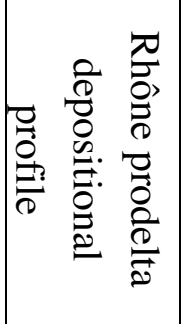 & 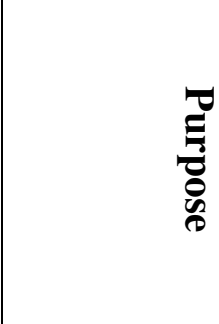 \\
\hline$\exists$ & $\vec{a}$ & $\overrightarrow{\breve{c}}$ & $\begin{array}{c}\overline{1} \\
\bar{u}\end{array}$ & $\begin{array}{l}\bar{r} \\
\dot{\nu}\end{array}$ & $\begin{array}{l}\vec{\omega} \\
\dot{\omega}\end{array}$ & $\begin{array}{l}\vec{\omega} \\
\dot{D}\end{array}$ & 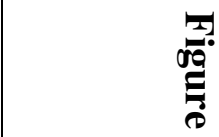 \\
\hline ț & $\begin{array}{l}\vec{w} \\
w\end{array}$ & 8 & $\vec{a}$ & $\vec{a}$ & $\begin{array}{l}0 \\
0 \\
0 \\
0 \\
0 \\
\tilde{D}\end{array}$ & 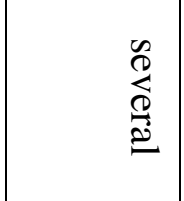 & 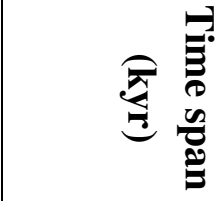 \\
\hline : & 인 & 인 & 이 & : & i & 임 & 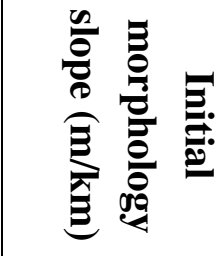 \\
\hline 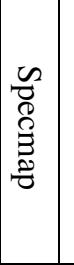 & 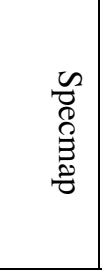 & 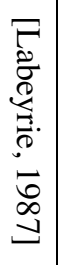 & 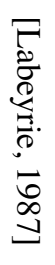 & 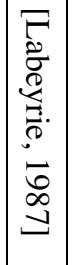 & 0 & 0 & 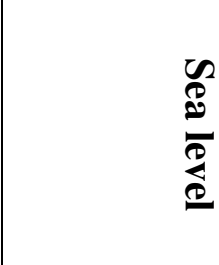 \\
\hline 峲 & $\begin{array}{l}\tilde{y} \\
0\end{array}$ & 岕 & 岕 & $\begin{array}{l}\tilde{N} \\
u\end{array}$ & 0 & 0 & 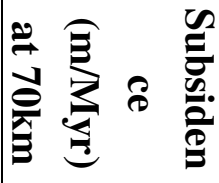 \\
\hline$a$ & $a$ & $\mathbb{\infty}$ & 8 & $\bar{u}$ & $\vec{u}$ & $\vec{u}$ & 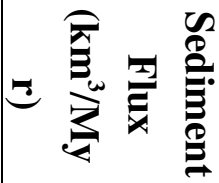 \\
\hline 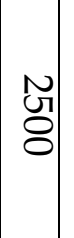 & $\begin{array}{l}\tilde{y} \\
\tilde{O}\end{array}$ & ज्ञ & $\overrightarrow{\mathrm{g}}$ & $\overrightarrow{8}$ & $\overline{\breve{g}}$ & $\overrightarrow{\tilde{\delta}}$ & 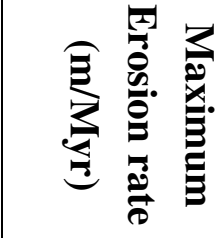 \\
\hline $\begin{array}{l}\omega \\
0 \\
n \\
1 \\
\vdots \\
a\end{array}$ & 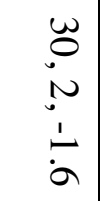 & $\begin{array}{l}8 \\
0 \\
n \\
\vdots \\
1 \\
0 \\
0\end{array}$ & $\begin{array}{l}w \\
0 \\
\vdots \\
\vdots \\
0 \\
\infty \\
\infty\end{array}$ & $\begin{array}{l}\omega \\
0 \\
0 \\
0 \\
0 \\
\infty \\
\infty\end{array}$ & $\begin{array}{l}w \\
0 \\
N \\
\vdots \\
\vdots \\
a\end{array}$ & $\begin{array}{l}. \\
0 \\
N \\
\vdots \\
\vdots \\
\sigma\end{array}$ & 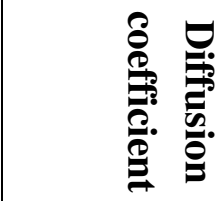 \\
\hline
\end{tabular}

